\title{
Geochronology, paleomagnetic signature and tectonic models of cratonic basins of India in the backdrop of Supercontinent amalgamation and fragmentation
}

\author{
1. Indian Statistical Institute, 203 B. T. Road, Kolkata, 700108, India \\ 2. Sedimentology Group, Wadia Institute of Himalayan Geology, Dehradun, 248001, India \\ * Corresponding author, E-mail: patranabis@gmail.com
}

(Received : 10/07/2019; Revised accepted : 12/09/2019)

https://doi.org/10.18814/epiiugs/2020/020009

The Proterozoic cratonic basins of peninsular India preserve records of repeated opening and closing of rifts along the zone of Neoarchean sutures and/or along the weak zones. These sedimentary basins, ranging in age from late Palaeoproterozoic through Neoproterozoic are traditionally referred to as Purana basins in Indian literature. The successions of each of the basins may be represented by successive unconformity-bound sequences, which represent several cycles of fluvialshallow marine to shelf-slope-basin sedimentation punctuated by local hiatuses and/or volcanic upheavals. The advance retreat of ancient seaways and their complex are recorded in the sedimentary successions of Purana basins.

Papaghni-Chitravati; Kaladgi-Badami; Lower Vindhyan record the oldest cycle of sedimentation. These basins opened after $2.0 \mathrm{Ga}$ and closed by $1.55 \mathrm{Ga}$. The Chattisgarh and its satellite basins, namely Indravati; Khariar; Ampani opened after the 1.6 Ga. and closed shortly after the 1000 Ma. Albaka; Mallampalli; Kurnool; Bhima preserve Neoproterozoic sedimentation history. The upper Vindhyan basin likely opened after 1.4 Ga. and continued through the Neoproterozoic. The sequence of events indicates a close relationship of craton interior histories with plate tectonics and variations in the heat flow regime underneath the continental crust. Periods of formation of the cratonic basins are coincident with the amalgamation or fragmentation of supercontinents further indicates genetic linkage between the two processes. Synchronous development of the cratonic basins with closely comparable stratigraphy and basin development events, in different small continents, strengthens the view that basin formation processes operated on a global scale, and stratigraphic basin analysis on a regional scale is a significant tool in evaluating the basins' history. The available stratigraphic, geochronologic or palaeomagnetic data from India is still inadequate, and further information is required to constrain its definite position in the context of global tectonics.

\section{Introduction}

An important stage of Earth's crustal history is marked by the Precambrian era spanning between $\sim 4550 \mathrm{Ma}$ and $540 \mathrm{Ma}$. Paleomagnetic geochemical and tectonostratigraphic data establish that the Precambrian era was a dynamic period when several configurations of the amalgamation and breakup of the supercontinents occurred. Records of this assembly/dispersal of continents and the dynamic evolution of our planet are read from the large-scale expression of geological features across the continents, and the study of the mantle underneath (Halverson et al., 2009; Cawood and Pisarevsky, 2006; Meert and Lieberman, 2004; Cocks and Torsvik, 2002; Tackley, 2000; Valentine and Moores, 1972). The presence of Precambrian orogenic belts in all major continents is often considered as the marker of ancient collisional or accretionary sutures, which provide us clues to the history of the periodic assembly of ancient supercontinents. Besides, the record of dispersal of the continents and release of enormous stress lie in extensional geological features, such as rift valleys, regionally extensive flood basalts, graniterhyolite terrane, anorthosite complexes, mafic dyke swarms and remnants of ancient mid-oceanic ridges. Testing of any of the models of assembly/break-up depends on precise age data and paleomagnetic pole reconstruction.

In this backdrop, this contribution aims to study all cratonic basins (Fig.1), which range in age from the Paleo- through Neoproterozoic and occupy more than one-fifth area of the Precambrian exposures of the Indian shield. Holland in 1907 coined the term "Purana basins" for these cratonic basins, which was widely accepted in Indian 
literature. The origin of these cratonic basins has been debated for decades, and none of the proposed models adequately explain the major elements of the basins or their subsidence history (for discussion, see, Basu and Bickford 2015; Thomson et al., 2014; Ingersoll, 2012; Allen and Armitage, 2012; Artemieva, 2007; Miall, 2005; Allen and Allen, 2005; Klein, 1995; Sloss, 1991). However, our limited knowledge indicates a close relationship of craton interior histories with plate tectonics and variations in the heat flow regime underneath the continental crust (Sloss, 1991; Gurnis,1988; Anderson, 1982). Periods of formation of many cratonic basins are coincident with the fragmentation of supercontinents (Hartley and Allen, 1994), indicating a genetic linkage between the two processes. Synchronous development of the cratonic basins with closely comparable stratigraphy and basin development events, in different small continents, strengthens the view that basin formation processes operated on a global scale, and stratigraphic basin analysis on a regional scale is a significant tool in evaluating the basins' history (Sloss, 1991, 1972; Soares et al., 1978). Tectonics of the craton, a manifestation of lithospheric dynamics, provides the over-riding control on stratigraphic development, as well as tectonic histories of the area. They are very closely monitored by the stratigraphic architecture of the basin-filling succession. Therefore, an inter-regional study of Purana basins could provide the platform for relating Proterozoic developments in the Indian craton with contemporaneous global tectonics. The available stratigraphic, geochronologic or paleomagnetic data from India is still inadequate, and further information is required to constrain its definite position. However, here we have tried to look back, based on available published data over the last two decades on geochronology, paleomegnetic studies and tectonic models, to understand the origin, expansion and demise of the cratonic basins of India in context of global tectonics within the two ancient well established supercontinent models i.e. Columbia ( 2.5-1.5 Ga with maximum packing around 1.9 to $1.7 \mathrm{Ga}$ ) and Rodinia ( 1.1-0.9 Ga with maximum packing around $1.1 \mathrm{Ga})$.

\section{Geological overview of the Indian shield}

The Indian shield is a mosaic of Archaean cratonic nuclei surrounded by Proterozoic orogenic belts, which preserve the records of geological events since the Palaeoarchaean/ Eoarchean. The $1600 \mathrm{~km}$ long Proterozoic orogenic belt, the Central Indian Tectonic Zone (CITZ) (Acharyya 2003) divides the Indian Precambrian shield into Northern Indian Block (NIB) and Southern Indian Block (SIB) (Zhao et al., 2002; Radhakrishna and Naqvi, 1986). The northern block consists of the Aravalli-Bundelkhand cratons, which amalgamated by 3300 Ma to form the stable Aravalli-Bundelkhand protocontinent (Mondal, 2009). Whereas, the Southern Indian Block (SIB) comprises the Dharwar- (including Southern Granulite Terrain), the Bastar-Singhbhum cratonic nuclei and the Eastern Ghats Belt (EGB) (Meert et al., 2010; French et al., 2008) (Fig.2). These cratons are composed mostly of granites, gneisses and remnants of greenstone/schist belts of the Archaean age and the cratonic basins (Purana basins) of Proterozoic age (Jayananda et al., 2018, 2016, 2015; Manikyamba et al., 2017; Saha et al., 2016; Saha and Mazumder, 2012; Meert et al., 2010; Chakraborty et al., 2010; Ramakrishna and Vaidyanadhan, 2008; Radhakrishna and Naqvi, 1986). Seismic studies and gravity modelling indicate the general crustal thickness of the Indian peninsular region to be about $35 \mathrm{~km}$ (Verma and Subrahmanyam, 1984; Kaila et al., 1979). 
The lithospheric thickness of the craton, on the other hand, varies from 65 to $148 \mathrm{~km}$ with an average of about $104 \mathrm{~km}$. with a high average reduced heat flow of $35 \mathrm{~mW} / \mathrm{m}^{2}$ and high average Moho temperature of about $550^{\circ} \mathrm{C}$ (Pandey and Agrawal, 1999). The heat flow regime of the craton and its lithospheric thickness are much higher than that found in many other major shield areas, which point to deformation and shearing at the lithospheric mantle level since the Mesoproterozoic (Pandey and Agrawal, 1999; Sass and Lachenbruch, 1979; Jessop and Lewis, 1978; Kutas, 1977; Chapman and Pollock 1974). Higher heat flow is attributed to high enrichment of lithophilic radioactive elements in the crust and upper mantle, caused by intermittent remobilization, rise of the isotherms and intrusion of granitoids since the stabilization of the Indian shield at ca. $2.5 \mathrm{Ga}$ (Rogers and Callahan, 1987).

\section{Cratonic basins of Peninsular India}

The Proterozoic sedimentary basins, distributed over four major cratons are the Lalsot-Bayana, Gwalior-Bijawar, Vindhyan and Marwar basins of Aravalli-Bundelkhand craton, Chhattisgarh and its satellite basins i.e. Khariar, Ampani, Indravati and Sukma basins of the Bastar craton, Pranhita-Godavari Valley (PGV) basin at the junction of Bastar and Dharwar craton, and Cuddapah, Bhima-Kaladgi basins of the Dharwar craton (Fig. 1). In general, all these basins overlie the Archean cratonic basements and preserve thick piles of unconformity bound sequences, which may be looked upon as successive sedimentation cycles, with prominent breaks in deposition. The depositional milieu of each of the cycles is manifested in the facies association, which represents the record of fluctuations in the sea level and often with changes in provenance through time. The stratigraphic development in each of the above intra/epicratonic sedimentary basins in Peninsular India is presented in the next sections and reviewed in the light of the geochronological data that emerged in the recent past.

\section{Basins of the Aravalli- Bundelkhand craton}

The Aravalli-Bundelkhand craton is a collage of two cratonic blocks: (1) The Banded Gneissic Complex-Berach granite (BBC), and (2) the Bundelkhand Granite massif (BKC) (Sharma 2009). Great Boundary Fault at the eastern limit of the BBC block marks the join between the two cratons. On the basis of disposition pattern, basins can be categorized into two types viz. i) basins hosted within and fringing the Aravalli craton (i.e. Latsot-Bayana and Marwar basins), ii) basin fringing the Bundelkhand craton (i.e. Bijawar-Gwalior and Vindhyan basins) (Fig. 1).

\section{Lalsot-Bayan basin}

The 1.8 Ga old (Deb and Thrope, 2004) NE-SW trending volcano-sedimentary succession at the eastern part of the North Delhi fold belt is thought to be deposited in an intracratonic rift setting (Figs. 1 \& 3). The basin fill sediments show paleoenvironmental products ranging in between terrestrial to deltaic/tidal deposition with shallow marine in between (Ahmed et al., 2005). Singh (1988) identified the 'Dausa uplift' as the source of the basin fill sediments. In addition, the Mesoarchean gneisses and the late Archean granites of Bundelkhand Gneissic Complex (BGC) are also identified as contributing source. Reccurent occurrence of conglomerates at different interval throughout the stratigraphic succession supports for tectonically guided sedimentation within the basin.

\section{Bijawar-Gwalior basin}

Situated at the southeastern and northwestern parts, respectively, of the Bundelkhand craton, Bijawar and Gwalior basins preserves the pre-Vindhayan sedimentation history and are regarded as contemporaneous in age (Fig.1). The emplacement ages of two phases of dykes within the basement of Gwalior Basin i.e. within the

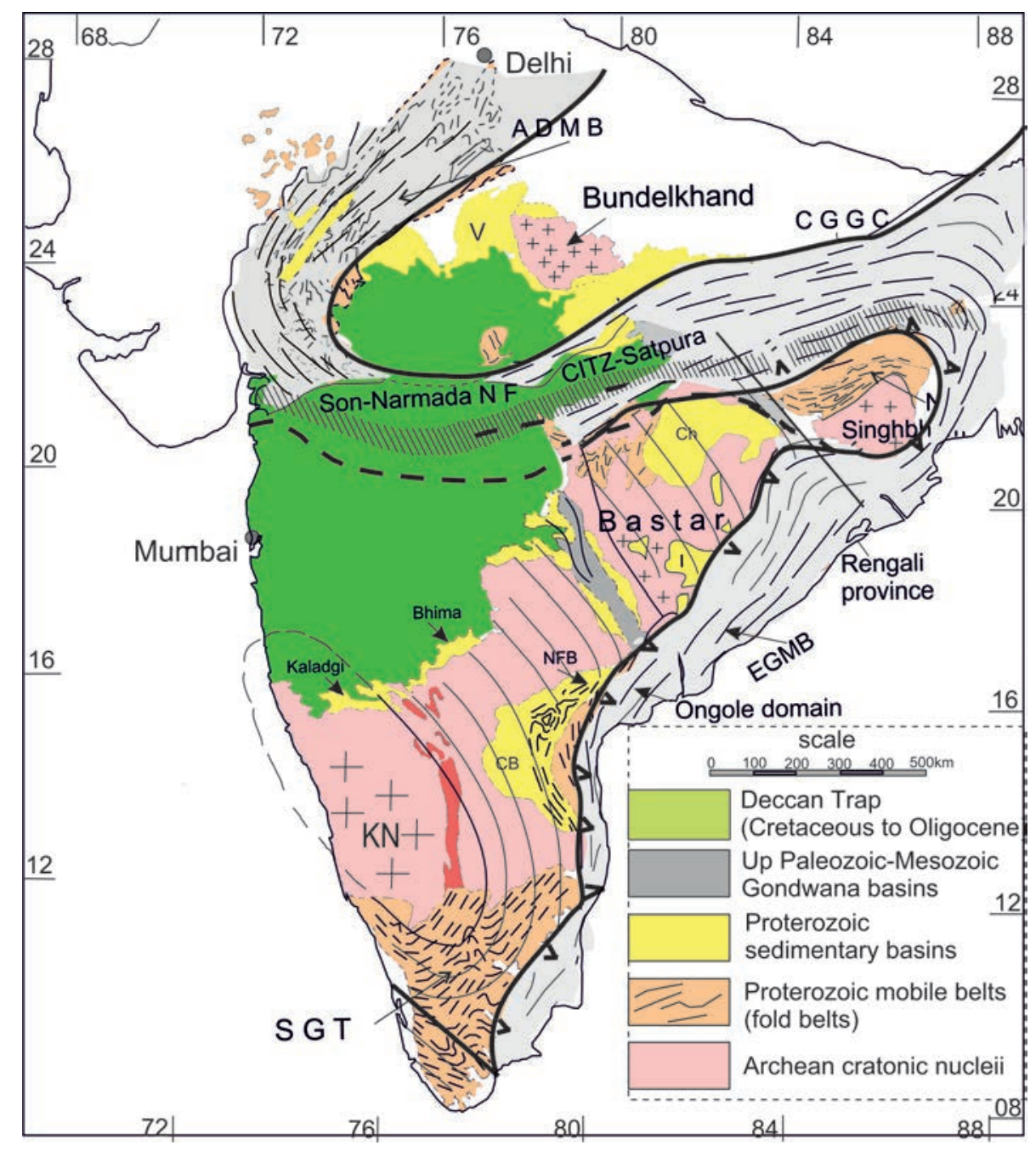

Figure 2. Geological map of Peninsular India showing the extent of major mobile belts (modified from Radhakrishna and Naqvi, 1986). 


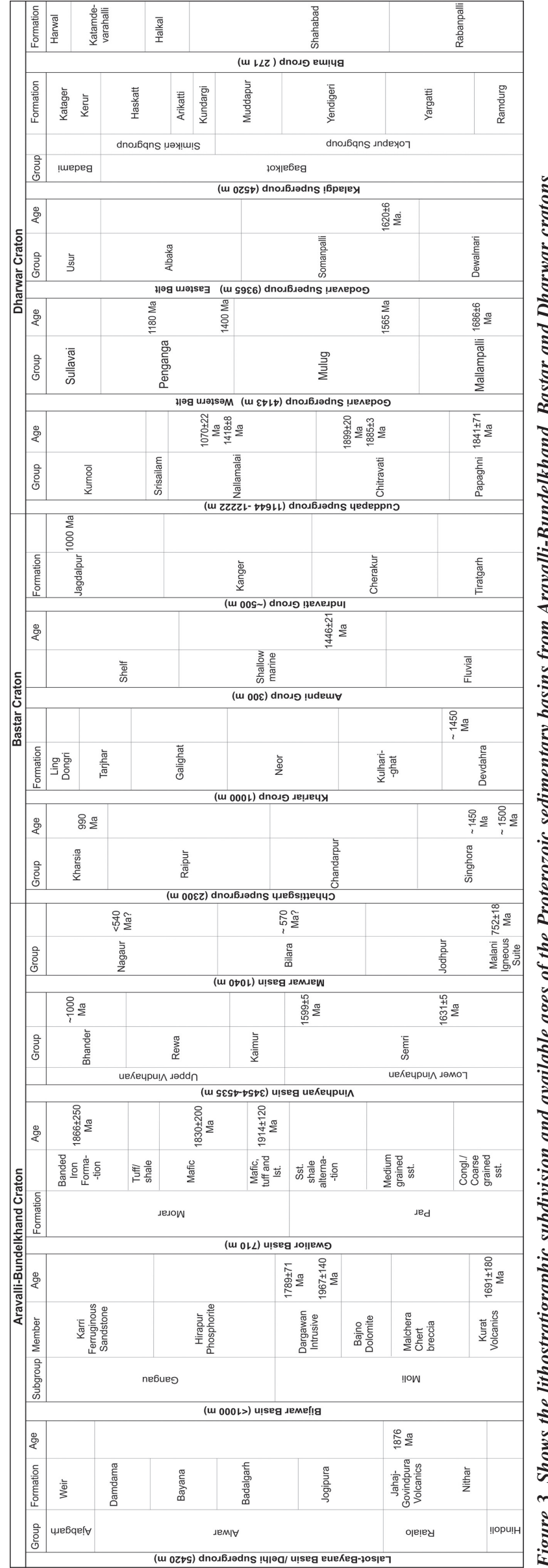

Bundelkhand Massif are $2150 \mathrm{Ma}$ and $2000 \mathrm{Ma}$, respectively $\left({ }^{40} \mathrm{Ar} /\right.$ ${ }^{39}$ Ar systematic; Rao et al., 2005). Rb-Sr dating of mafic rocks present within the basin has yielded dates of $1830 \pm 200 \mathrm{Ma}(\mathrm{Rb}-\mathrm{Sr}$ isochron; Ramakrishnan and Vaidyanadhan, 2010) and $1854 \pm 7 \mathrm{Ma}(\mathrm{U}-\mathrm{Pb}$ zircon concordia; Deb et al., 2002), respectively. Taking the dates into consideration, Absar et al. (2009) bracketed the Gwalior depositional history between 2000 and 1791 Ma. From the Bijawar Basin the Dargawan sill and the Kurat lava are dated as $1789 \pm 21 \mathrm{Ma}$ and $1691 \pm 180 \mathrm{Ma}$, respectively using Rb-Sr systematics (Haldar and Ghosh, 2000) (Fig.3).

Despite being coeval, analogous rift-related tectonic setting and sediment supply from a common provenance i.e.the BGC, the Gwalior and Bijawar basins vary in their sedimentation patterns. While clastic sedimentation ranging between continental (alluvial fan and braided fluvial) and proximal shelf set-up mark early sedimentation in the Gwalior basin (Chakraborty and Paul, 2014; Paul, 2017), the Bijawar basin records early chemical sedimentation in terms of Bajno Dolomite and Malhera Chert Breccia Formations with a very early, restricted record of volcano-clastic sedimentation in the form of the Kawar Formation. Sedimentation patterns differ in the later parts of depositional histories of the two basins as well. Whereas the Gwalior Basin records BIF of ca. $1.85 \mathrm{Ga}$ time period as Morar Formation, the Bijawar Basin registers phosphorite deposition (Chakraborty et al., 2015; Absar et al., 2009; Absar, 2005). In general, both the basins have been identified as deposition within a half-graben rift-related tectonic setting.

\section{Vindhyan basin}

The Vindhyan basin with an outcrop area over about $60,000 \mathrm{~km}^{2}$, is the largest among all the 'Purana Basins' and second largest among all the Proterozoic basins of the world (Chakraborty, 2006) (Fig.1). Son Valley Vindhyans and the Aravalli-Vindhyans are two sub-basins situated east and west of the Bundelkhand granite (Mondal et al., 2002; Crawford and Compston, 1970). Aravalli-Delhi orogenic belt (2500-900 Ma; Roy, 1988) marks the western boundary while the Satpura orogenic belt (1600-850 Ma; Verma, 1991) marks the southern boundary of the Vindhyan outcrop.

The Vindhyan Supergroup unconformably overlies the Basement granite-gneiss of the Aravalli-Bundelkhand craton and early Proterozoic sediments of Bijawar and Gwalior Groups. The succession is divided into two unconformity-bound sequences viz. Lower and Upper, based on a basin-scale unconformity. Lower sequence includes Semri Group while the Upper sequence, includes Kaimur, Bhander and Rewa Groups. Age constraints for the initiation of sedimentation are obtained as $\sim 1631 \mathrm{Ma}$ (U-Pb zircon) from the Porcellanite Formation of the lowermost Semri Group (Rasmussen et al., 2002; Ray et al., 2002), while $\mathrm{Pb}-\mathrm{Pb}$ age from the Kajrahat Limestone below the Porcelanite Formation indicate that the initiation of sedimentation in the Vindhyan basin is earlier than 1721Ma (Sarangi et al., 2004; Ray, 2006). However, reliable radiometric age data for the upper Vindhyan rocks are still lacking or not compatible with different methods of dating. Here to mention that the uppermost strata of the Vindhyan basin is dated to be ca. 900-1000 Ma by the Pb-Pb age of three limestone units (Gopalan et al., 2013), as well as paleomagnetic pole reconstruction and provenance arguments from detrital zircon geochronology (e.g., Davis et al., 2014; Turner et al., 2013; Malone et al., 2008). In contrary, the fossil assemblages from the same set of strata indicates the Ediacaran period (Pandey and Kumar, 2013; Kumar 
and Pandey, 2010; Srivastava, 2009; Kumar and Pandey, 2008; Sharma 2008; Prasad, 2007; Maithy and Kumar, 2007; De, 2006; Rai and Singh, 2004). Seilacher et al. (1998) reported Metazoan trace fossils, while annulated tubes and coccoidal microbial fabrics similar to the Cambrian records elsewhere have been reported by Bengtson et al.(2009). Majhgawan kimberlite pipes, within the Kaimur Sandstones of the upper Vindhyan gives an age 1075 Ma by $\mathrm{Ar}-\mathrm{Ar}$ method pointing towards its deposition prior to $1075 \mathrm{Ma}$ (Gregory et al., 2006). Comparing Sr isotope evolution curve Ray et al. (2003) suggested the Bhander limestones of upper Vindhyan to be deposited between 750 and 725 Ma (Fig.3).

Sedimentological analysis of each of the Groups points towards deposition in coastal fluvial to marine set up, represented by the fan delta and braid delta system with the occasional presence of eolian sandsheets. The fluvio-deltaic coastal environment passes up to open marine shelf environment with intermittent reworking by tide and storm (Banerjee et al., 2014; Banerjee and Jeevankumar, 2005; Chakraborty et al., 1998; Akhtar, 1996; Prasad and Verma, 1991; Soni et al., 1987; Singh, 1985; Chanda and Bhattacharya, 1982; Banerjee, 1974). Northwesterly flow paleocurrents in the Son-valley sector and southerly flow paleocurrents in the Bundelkhand sector respectively points to Satpura orogen to be the source first and the Bundelkhand Granite Gneiss, Bijawar and Gwalior Group of rocks to be the source for the later (Chakraborty 2006; Bose et al., 2001).

The Semri Group comprises dominantly of carbonates, siliciclastics with intercalated pyroclastics and volcaniclastics. Deoland conglomerate is the basal conglomerate, mostly debris-flow deposit (Banerjee et al., 2008). The Kajrahat Limestone and the Rohtas Limestone are the two important carbonate units of the Semri Group, which developed as shallow to deep marine carbonate platform with prolific development of stromatolites (Banerjee and Jeevankumar, 2007; Banerjee et al., 2007). Volcanic exhalation disrupted the Kajrahat Limestone deposition. Finally, the carbonate production stopped when Porcellanite unit was deposited. Field observation reveals lateral facies variation, especially in the clastic units in eastern and western sectors. The coarse-grained clastics of the basal Kaimur Group are only present in the Bundelkhand area, while the shalelimestone succession in the upper part is present in both Son valley and the Bundelkhand area. The basal part of the Rewa Group occurring in the northern part of the Son valley is represented by conglomerates and arkosic sandstones, which have no equivalent in the southern part (Bose et al., 2001, 1997). However, the overlying units are correlatable across the entire outcrop of the Vindhyans in the Son valley. The uppermost Bhander Group consists of thick carbonate units, which developed as an extensive stromatolitic platfoms, alternating with shale and minor siliciclastic or oolitic sandstone. Very well-preserved sections with excellent preservation of sedimentary features, little diagenetic alternation, especially of the carbonates facilitates facies analysis and palaeoenvironmental studies by different workers through ages (Banerjee et al., 2007; Chakraborty, 2004; Bose et al., 2001; Chakraborty and Chakraborty, 2001; Bose et al., 1999; Singh, 1980).

Since the Aravalli, Delhi and Satpura orogenic belts border it, some workers considered the basin as a peripheral foreland basin related to the southerly dipping subduction prior to the collision of Bastar and Bundelkhand cratons (Chakraborty and Bhattacharyya, 1996; Raza and Casshyap, 1996). Chakraborti et al. (2007) supported the idea from $\mathrm{Nd}$ isotope study. Other views include intracratonic rift origin (Ram et al., 1996;Verma and Banerjee, 1992). Bose et al. (2001) correlated the sedimentary and geophysical attributes to an intracratonic rift to sag transition. Amongst all these models, a broad consensus that prevailed in literature is a westward opening epicontinental basin model (Bose et al., 2001; Chanda and Bhattacharyya, 1982; Banerjee, 1974).

\section{Marwar basin}

Overlying 700 Ma (681 Ma to 771 Ma; Gregory et al., 2009; Torsvik et al., 2001) old Malani Igneous Suite (MIS) of rocks, sedimentary succession of the Marwar Supergroup is subdivided into lowermost Jodhpur Group, middle Bilara Group and uppermost Nagaur Group (Chauhan, et al., 2004;Pareek, 1984) (Fig.1 \& 3). From putative traces of trilobite in the upper part of the Nagaur Group, Kumar and Pandey (2008b) claimed Paleozoic time frame for the Nagaur rocks. McKenzie et al. (2011) estimated LA-ICPMS detrital zircon maximum age of 540 Ma from sandstones of the Nagaur Formation. In the absence of fossil evidence, Ansari et al. (2018) relied on ${ }^{87} \mathrm{Sr} /{ }^{86} \mathrm{Sr}$ and $\mathrm{Ca} / \mathrm{Sr}$ values to infer probable age of Gotan Limestone of Bilara Group as 520-530 Ma and 570 Ma. A serious question is posed with the arrival of these new dates on the validity of the assumption that the Marwar Supergroup is a continuation of the Vindhyan Supergroup across Aravalli axis (cf. Shrivastava, 1971; Heron, 1932).

\section{Basins of the Bastar craton}

The Bastar craton is delimited by Upper Paleozoic-Mesozoic rifts, namely, the Mahanadi Rift and Pranhita-Godavari Valley Rift in the northeast and southwest, respectively and host a number of sedimentary basins which are virtually unmetamorphosed, partly deformed and contain arkose-quartz arenite, limestone-dolomite and shale with subordinate conglomerate, evaporite and felsic ignimbrite. The largest of these basins is the Chhattisgarh basin, which occurs in the northern part of the craton. Khariar, Indravati, Ampani and Sukma are other relatively smaller basins, mostly referred to as 'satellite basins of the Chhattisgarh', occur in the southeastern sector of the craton (Fig.1).

\section{Chhattisgarh basin}

Chhattisgarh Basin (Fig.1) covers an area over $36000 \mathrm{~km}^{2}$ and host 2300 m-thick sedimentary succession of Meso- to Neoproterozoic age (Das et al., 1992; Patranabis-Deb and Chaudhuri, 2008; Chakraborty et al., 2002, 2009). The basin filling succession unconformably overlies the Archean crystalline basement, and the Neoarchean to Palaeoproterozoic Dongargarh-Kotri volcanics. Murti (1987) first proposed a comprehensive stratigraphic classification, where he clubbed coarse siliciclastic dominated Chandarpur Group and unconformably overlying limestone-shale dominated Raipur Group, into Chhattisgarh Supergroup. Later, Das et al. (1992) envisaged two sub-basins, i.e. the Baradwar sub-basin and Hirri subbasin in the eastern and western parts, respectively. Their study reveals that the Barapahar proto-basin records the basin initiation stages and classified the succession as a separate stratigraphic entity, the Singhora Group and assigned a stratigraphic position below the Chandarpur Group. However, Das et al., (1992) defined three Groups in the Baradwar sub-basin, the middle and the upper one of which correspond to the Chandarpur Group and the Raipur Group of Hirri Sub-basin, respectively. Patranabis-Deb and Chaudhuri (2007a) have 
identified a younger unconformity-bounded sequence, the Kharsiya Group, above the Raipur Group. The sandstone-shale assemblage of the Kharsiya Group is a lateral facies equivalent of the uppermost shale-dolomite succession of the Hirri sub-basin. The sedimentary succession of the basin thus may be looked upon as four successive unconformity bound successions of group status, namely, Singhora, Chandarpur, Raipur and Kharsiya (Chakraborty et al., 2015b;Saha et al., 2013; Patranabis-Deb and Chaudhuri, 2008, 2010) (Fig.3).

Volcaniclastic interbedded units near the base of the Chhattisgarh succession (i.e. from Singhora Group) has been dated at 1500 Ma (Das et al. 2009; EPMA, Monazite) and at 1450 Ma (Bickford et al., 2011; SHRIMP, zircon). The time of the basin opening is thus inferred to be at around $1.5 \mathrm{Ga}$ to $1.4 \mathrm{Ga}$. The upper part of Raipur Group preserves welded tuff, which yielded U-Pb zircon age of $~ 1000$ Ma (Patranabis-Deb et al., 2007b). Therefore, available geochronological data point towards the Mesoproterozoic origin of the Chhattisgarh basin. Sm-Nd mineral-whole-rock isochron age of 1421 Ma from a mafic dyke that intruded the sedimentary rocks near Singhora village is also being reported (Das et al., 2011). Moreover, the basin fill sediments were also studied for its detrital zircon (Das et al., 2017; Bickford et al., 2011). Das et al. (2017) showed that there was a change in source during the initial phases of the evolution of Chhattisgarh basin in course of Singhora Group deposition (Fig.3).

Lowermost Singhora and middle Chandarpur Group comprise $\sim 400 \mathrm{~m}$ and $\sim 600 \mathrm{~m}$ thick immature to mature siliciclastic succession, respectively. Products of continental (alluvial fan, Chakraborty et al., 2009; Patranabis-Deb and Chaudhuri, 2007; and braid plain, Chakraborty and Paul, 2005; Paul and Chakraborty, 2003), transitional (shoreface, foreshore and beach, tidal estuary and delta; Chakraborty and Paul, 2008; Patranabis-Deb and Chaudhuri, 2002); shallowmarine (storm-dominated, intertidal and subtidal, occasionally lagoonal; Patranabis-Deb and Chaudhuri, 2002;Das et al., 1992, 2001; Datta et al., 1999) and distal marine below wave base (Chakraborty and Paul, 2008) are documented from different stratigraphic levels from the siliciclastic intervals. The carbonate-shale succession of the Raipur Group with minimal input of sandy clastics ( $<0.1 \%)$ represents the passive subsidence stage of basin evolution (Patranabis-Deb and Chaudhuri, 2008). The stratigraphy of the Chandarpur-Raipur Groups is typical of a passive margin basin. The Kharsiya Group unconformably overlies the Chandarpur-Raipur Groups and consists of a basal conglomerate with clasts of welded tuff, sandstone, chert, feldspathic sandstone and sand-mud heterolithic rocks, deposited in fluvial to shallow marine shelf bar environments. Gradually the coast was inundated with slow and a steady rise of the sea level depositing a thick pile of shale and dolomite. Finally, the basin closed with the development of shallow halite pans on the top-most part of the succession represented by the Maniari/Nandeli Shale.

Das et al. (1992) identified the sediments deposited in an intracratonic sag setting. Whereas, Patranabis-Deb et al. (2007) taking under consideration the basin margin faults and calc-alkaline magmatism in the surroundings of the basin argued for an intracratonic rift depositional setting. Biswal et al. (2003) and later Paul (2006) proposed a foreland basin model for the origin of the Chhattisgarh basin. In recent times detailed structural studies (Saha et al., 2013), consideration of the geochemical characters of the volcaniclastic units which shows a volcanic-arc related setting (Das et al., 2015, 2009) and identification of an western dipping remnant slab at a depth of $200 \mathrm{~m}$ (Ramesh et al., 2010) it may be presumed that atleast initiation of the basin was in a foreland mode related to the subduction of Bastar craton and/ or a craton which was immediate neighour to India at around $1.8 \mathrm{Ga}$ at the eastern margin of Indian subcontinent.

\section{Khariar basin}

N-S elongated tear-drop shaped outcrop of the Khariar basin covers $1500 \mathrm{~km}^{2}$ area of the Bastar craton (Fig. 1). The basin fills succession ( 300 m) unconformably overlies the basement granite complex and the 1466 Ma Lakhna dyke swarm (Pisarevsky et al., 2013; Ratre et al., 2010). Datta (1998) subdivided the succession into three informal units on the basis of lithology, and depositional environment, which later on were assigned to be formal lithostratigraphic status as the Pairi Group, with six units of formation level (Das et al 2003). Das et al. (2009) obtained a $1455 \pm 47$ Ma age through U-Th-total Pb EPMA geochronology of monazite and zircon grains from porcellanitic tuffaceous units from the lowermost part of the succession and equated it with the Singhora Group of rocks of the Chhattisgarh Supergroup (Fig.3).

\section{Ampani basin}

Ampani basin occupies $\sim 220 \mathrm{~km}^{2}$ area, south of Khariar basin and unconformably overlies the Bastar granite-gneiss complex (Fig.1). The $\sim 300 \mathrm{~m}$ thick siliciclastic package shows paleo-environmental products ranging from continental fluvial through shallow marine to deep marine depositional set-up, deposited in a transgressive mode (Fig.3) (Chakraborty et al., 2017). Both basement and cover rocks show evidence of pervasive deformation. Das et al. (2015) reported an age of 1446 Ma from the interbedded porcellanites occurring in the middle part (Shallow marine) of the litho-stratigraphic succession. Detrital zircon analysis encompassing the whole lithostratigraphy shows clear evidence of change in the provenanceduring deposition of the shallow marine succession. The Archean to Palaeoproterozoic sources dominates the lower part of the Ampani succession. The supply of detritus from the Archean rocks stopped in the middle part of the stratigraphic column. Finally, the upperpart of the succession received sediments from the Mesoproterozoic source rocks (Saha et al., 2016).

\section{Indravati basin}

Indravati basin covers an area of $\sim 900 \mathrm{~km}^{2}$ of the Bastar craton (Fig.1). Ramakrishnan (1987) formally divided the succession into four mappable units namely Tiratgarh, Cherakur, Kanger and Jagdalpur Formations making up the Indravati Group. Apart from broad lithological descriptions no process-based sedimentological understanding is available in the literature. Kimberlite pipes, pyroclastic breccia and tuffs are reported from different stratigraphic intervals of the Indravati succession (Das et al., 2001)

The Tokapal and Bhejripadar kimberlite pyroclastics, hosted within the Kanger Formation but below the Jagdalpur Formation (Mainkar et al., 2004), have yielded a LA-ICPMS U-Pb age of 620 \pm 30 Ma from autometasomatic titanite (Lehmann et al., 2007). The stratigraphic position ofthe Tokapal Tuff in the uppermost part of the Kanger Formation indicates an unconformity between the Kanger and Jagdalpur Formations (Ramakrishna and Vaidyanadhan, 2010; Lehmann et al., 2006, 2007; Mainkar et al., 2004; Chaudhuri et al., 1999). However, isotopic analyses (LA MC-ICPMS) of the zircons 
from the Birsaguda Tuff, within the Jagdalpur Formation point to closure of the basin at 1001 \pm 7 Ma (Mukherjee et al., 2012) (Fig.3).

\section{Sabari (Sukma) basin}

The sedimentary succession of the Sabari basin (Fig.1) is exposed over $700 \mathrm{~km}^{2}$ area, south of the Indravati basin. Khariar, Indravati, Ampani and Sabari basins occur in a line along the eastern margin of the Bastar craton, parallel to the Eastern Ghats Mobile Belt (EGMB). The close proximity of the basins to the mobile belt and synchronous origin implies their relationship with the tectonic scenario. The Sabari succession consists of conglomerate, sandstone, shale and limestone deposited in coastal and shallow shelf environment. Detail facies analysis and paleo-environmental modeling, sequence modeling, sediment geochemistry and geophysical patterns for these basin fills are very limited (Chakraborty et al., 2010). Ramakrishnan (1987) has given a detail description of the lithologies and correlated the succession with the Indravati succession, but no formal stratigraphic divisions are proposed yet.

\section{Basins of the Dharwar craton}

The Dharwar craton is the largest cratonic block of peninsular India, comprises two distinct tectonic blocks, East Dharwar Craton (EDC) and Western Dharwar Craton (WDC) with Closepet granite at the juncture. The Closepet granite represents the amalgamation and final cratonization event at $\sim 2.5 \mathrm{Ga}$. The sedimentary basins, Cuddapah and Pranhita-Godavari basin of EDC unconformably overlies Dharwar batholith (Chadwick et al., 2000) with remnants of greenstone belts (c. $2.7 \mathrm{Ga}$ ), which form linear arrays (Jayananda et al., 2012; Ramakrishnan and Vaidyanadhan, 2008; Naqvi and Rogers, 1987). On the northern fringe of the EDC lies the younger Bhima basin (Joy et al., 2018; Jayaprakash, 2007) while Kaladgi basin overlies the Archaean basement of the WDC, and in turn is overlain by the Decan trap in the NW (Fig.1).

\section{Cuddapah basin}

The crescent-shaped Cuddapah basin covers about $45000 \mathrm{~km}^{2}$ area, in the eastern part of the EDC, unconformably overlies the Archaean granitoids, including, greenstone belts and the dyke complexes (Fig.1). The eastern margin of the basin is marked by a prominent boundary thrust, which is parallel to the Nellore Schist Belt (NSB) and the Nallamalai fold belt (NFB) (Saha et al., 2010; Saha and Chakraborty, 2003). Cuddapah basin comprises of four subbasins namely Papaghni, Kurnool, Srisailam and Palnad (Nagaraja Rao et al., 1987). It is a poly-history basin hosting 8-10 km thick sedimentary successions ranging in age from the Palaeoproterozoic through the Neoproterozoic with internal unconformities. The succession of the Cuddapah basin, designated as Cuddapah Supergroup, has been classified into four unconformity bound sequences marking syn-to-post-rift cycles of deposition (Saha and Tripathy, 2012; Patranabis-Deb et al., 2012). Each cycle starts with the deposition of conglomerates, immature feldspathic sandstones representing syn-rift immature clastic deposits, which pass up to a highly mature quartz-arenite-carbonate succession pointing to postrift, passive subsidence stage of deposition. The sedimentary succession of the basin experienced intense igneous activity at different stratigraphic levels during and post-depositional phases.
Radiometric dating by Ar-Ar method of mafic dykes/sills within the Tadpatri Formation of Chitravati Group of Cuddapah Supergroup (Fig. 3) suggests the sedimentation started before $1.9 \mathrm{Ga}$ (Collins et. al., 2015;French et al., 2008;Anand et al., 2003). Mafic sills/ and dykes intruded the Vempalle succession at different stratigraphic levels yield a series of dates from 1879 and 1899 Ma (Anand et al., 2003; Chatterjee and Bhattacharji, 2001;Bhaskar Rao et al., 1995). A lower limit to the onset of deposition is provided by $2.2 \mathrm{Ga}$ ages for dolerite dyke swarms that intruded the EDC lithologies but not the overlying Cuddapah formations. Pb-Pb dating of uranium mineralized and barren Vempalle dolomites yielded an age of 1943 \pm 27 Ma (Rai et al., 2015). Zachariah et al. (1999) proposed $1756 \pm 29 \mathrm{Ma}, \mathrm{Pb}-\mathrm{Pb}$ date of the dolomite hosted Ur mineralized horizons of Vempalle and Tadpatri Formation. An upper age constraint of 1400 Ma for the Cuddapah deposition is provided by the ages for lamproite dykes intrusive to Cumbum shale, between 1354 and 1418 Ma (Chalapathi Rao et al., 2016, 1999, 1996; Kumar et al., 2001). The uppermost limit of the sedimentation in the Kurnool Group is assumed to be $>1.1 \mathrm{Ga}$, based on the carbonate and limestone xenoliths that were presumably derived from these horizons and hosted the $1.1 \mathrm{Ga}$ Siddanpalle kimberlites of the Raichur kimberlite Field (Chalapathi Rao et al., 2010).

From detrital zircon, Hf isotope data and detrital muscovite ${ }^{40} \mathrm{Ar} /$ ${ }^{39} \mathrm{Ar}$ data of stratigraphically constrained samples from all the main depositional units within the Cuddapah Basin, Collins et al. (2015) identified that the Dharwar Craton was the sediment source for Papaghni and lower Chitravati Groups, in a riftogenic mode and evolved into a passive margin basin with time. The Neoproterozoic Kurnool Group saw a return toDharwar Craton derived provenance. Joy et al. (2018) reported mixing of older sources (3.9 Ga, 3.5 Ga) and 2.6 Ga source from the detrital zircon study of the Cuddapah sediments. Pre- or syn-depositional dolerites, including Tadpatri sills of the Lower Cuddapah succession indicates its deposition in between 2.2 Ga and $1.86 \mathrm{Ga}$. The Nallamalai succession is constrained in age between $1.58 \mathrm{Ga}$ to $1.38 \mathrm{Ga}$; represented by the youngest zircon population of the Bairenkonda Formation of the Nallamalai Group, the syenites intrusive in the Cumbum shales and from the approximate age of the Chelima lamproites, respectively. The Srisailam succession is dominated by tidal deposits with aeolian intercalations (clean quartzites), that have yielded Archean zircons (no Proterozoic zircons recovered) and the age of deposition is constrained from field relations only (sediments unconformably overlie Cumbum shales and in turn are overlain by Banganapalle conglomerates. The Banganapalle Quartzite Formation, the placer diamond-bearing conglomerate of the Cuddapah Basin is sourced from kimberlites of the Wajrakurur cluster. De Beers' India's exploration efforts have resulted in the discovery of a number of dykes within the basin, with petrographical and geochemical similarities to lamproites. These dyke-sill complexes at 1.4-1.3 Ga and the lamproites are identified as the source of the diamonds in the Banganapalle conglomerates. Eastern Ghats Mobile Belt (EGMB) provided a pivotal role during the lamproite emplacement by creating an extensional field (Joy et al., 2012).

\section{Pranhita-Godavari Valley (PGV) basin}

The Pranhita-Godavari Valley (PGVs; Fig. 1) preserves the records of multiple Proterozoic rifting and a Gondwana rifting, each opening and closing along the same zone inherited from the Neoarchean orogen (Chaudhuri, 1985; Srinivasa Rao et al., 1979; Subba Raju et al., 1978; 
Basumallick, 1967). The rift, bounded along its southwest margin by granites and granulites of the Karimnagar Granulite Belt (KGB) with a peak metamorphism age of c. $2600 \mathrm{Ma}$, and on the northeast margin by the Bhopalpatnam Granulite Belt (BGB) with a peak metamorphism age of c. 1600 Ma marks the join between the Dharwar and Bastar craton, (Chaudhuri et al., 2012; Chaudhuri and Deb, 2004; Santosh et al., 2004; Mishra et al., 1999; Naqvi and Rogers, 1987). The PGV basin and flanking granulites join the EGMB to the southeast and the Central Indian Tectonic Zone (CITZ) to the northwest as interpreted from geophysical studies (Biswas, 2003). Based on reconstructed basin palaeogeography, it has been proposed by Chaudhuri (2003) that the basin margins of PG valley extended signiûcantly beyond the present-day outcrops. The northwestern part of the basin is concealed by late Cretaceous ( 60Ma) Deccan basalt (Biswas, 2003) and the SE part possibly was continuous with the Cuddapah Supergroup outcrops (Chaudhuri 2003). Rogers and Santosh (2004) considered the Proterozoic outcrops of the valley to be the key element in the reconstruction of the Palaeoproterozoic supercontinent Columbia.

${ }^{40} \mathrm{Ar} /{ }^{39} \mathrm{Ar}$ age dates of early authigenic glauconites from several stratigraphic intervals (Conrad et al., 2011) suggest that the basin history dates back to about $1700 \mathrm{Ma}$ and opens up the possibility of interpreting the tectonic evolution of the basin in a global perspective. The stability of the craton was disrupted when the first major cratonic rift nucleated at c. $1620 \mathrm{Ma}$, and shortly evolved into an oceanic basin along the northeastern margin of the Valley with consanguineous deposition of a thick wedge of conglomerates, tidal sandstones and shales in the Mulug shelf, and a succession of graywacke, carbonate, siltstone-mudstone-black shale and tuff turbidites of the Somanpalli flysch in two parallel adjoining belts (Chaudhuri et al., 2012) (Fig.3).

The Proterozoic succession in the Valley is characterised by unconformity bound sedimentary sequences deposited in variable modes of sedimentation, staring from fluvial, shallow marine to deepsea environment, under diverse tectonic condition (Amarasinghe et al., 2015; Chaudhuri et al., 2015; Chaudhuri et al., 2012; Conrad et al., 2011; Chaudhuri, 2003; Saha and Patranabis-Deb, 2014). They crop out along the margins of the craton with NW-SE trending Eastern and Western belts now separated by the axial outcrop of the Upper Paleozoic -Mesozoic Gondwana succession. Analysis of sedimentary attributes of unconformity-bound sequences indicates that Purana sedimentation in the Valley started with the deposition of stable platform assemblage of carbonate-quartz arenite in an extensional sag basin. More recently, four major unconformity bound successions are identiûed in each eastern and western belt of the PGV Basin. In the western belt the Mallamapalli and Mulug Groups are clubbed under Pakhal Super Group, which is overlain by Penganga and Sullavai Groups. Chaudhuri (2003) suggested Supergroup status for the four distinct unconformities bound units deposited in shallow shelf to fluvial to aeolian environment of the western belt and named Godavari Supergroup (Chaudhuri, 2003). Devalmari, Somanpalli, Albaka and Usur Groups in the eastern belt (Saha and PatranabisDeb, 2014; Conrad et al., 2011; Chaudhuri et al., 2015) are being correlated with the western belt units in ascending order (Fig. 3). In the eastern belt, the Somanpalli Group consists of a thick succession of tidal sandstones with associated black shales, mudstones and siltstones, with intervals of deep-water carbonates, ash tuffs and greywackes (Conrad et al., 2011).

Paleogeography reconstructions of the Pakhal Group suggest that the PGV basin was a continental margin marine basin that opened to the east towards present day Eastern Ghats belt (Chaudhuri, 2003). In absence of any direct physical relationship between the Mulug Subgroup and Somanpalli Group, their relationship could not be established in the field. However, they were interpreted, on the basis of regional stratigraphic considerations, to have developed as two parallel belts within a protracted rift system, the former as a shallow tidal shelf deposit and the latter as a deep water slope and continental rise deposit (Chaudhuri et al., 2012). Sedimentation in this inferred shallow water-deep water couplet was terminated by major contractional deformation producing a fold-and-thrust belt (Ghosh and Saha, 2005, 2003;Saha 1988), later designated as the Somanpalli orogenic belt (Chaudhuri et al., 2012). The age of basin inversion coincides with the closure of the Mulug and Somanpalli basins and pre-dates deposition of the Penganga sequence which overlies the Mulug Group with a major erosional unconformity. The cycle records a complete cycle of rifting and opening of a new ocean basin.

\section{Bhima Basin}

The NE-SW trending Bhima Basin, with an area of $5200 \mathrm{~km}^{2}$ unconformably overlies the Archaean basement of the EDC and in turn, is mostly covered by end Cretaceous Deccan Trap flows and inter-trappean beds (Fig.1). The sedimentary succession is thin compared with other Purana basins, with a maximum thickness of 273 m (Mishra et al., 1987). The Bhima Group is subdivided into five formations representing clastic carbonate cycles (Jayaprakash et al., 1987). The succession starts with a thin clastic unit, the Rabanapalli Formation $(67 \mathrm{~m})$, gradationally overlain by a very thick carbonate unit, the Shahabad Formation (115 m), followed by Hulkal shale (30 m), Katamdevarahalli Limestone (40 m) and Harwal shale (45 m) (Fig.3). The Rabanapalli Formation includes conglomerates, granulestone, pebbly sandstones, and quartz arenites with thick bedded planar and cross stratified sandstones alternating with planar parallel bedded types, which reflect a shallow shelf environment of deposition. The overlying Shahabad Formation is a limestone-marl rhythmite ("flaggy limestone"). Detailed facies classification and cyclicity analysis of the Shahabad Limestone shows that it represents a nonrimmed carbonate platform (Patil Pillai and Kale, 2019; Joy et al., 2018; Saha et al., 2016). A major transgression and deepening of the basin with development of euxinic condition and deposition of black limestone with authigenic pyrite points towards the development of an anoxic ocean basin during maximum transgression (Patranabis Deb et al., 2016; Wignall, 1994; Chilingar et al., 1967). The deposition of the Halkal shale may be taken as the cause of the demise of the carbonate platform. However, the carbonate factory resumed its production with a drastic change in the environment, reducing the siliciclastic input, which is represented in the rock record by sharp contact between the two formations.

\section{Kaladgi Basin}

The Kaladgi Basin occupies an area of about $8000 \mathrm{~km}^{2}$ along the northern boundary of the WDC and exposes 3900 m thick succession (Radhakrishna and Vaidyanadhan, 1994;Jayaprakash et al., 1987) (Fig.1). Metasediments of Dharwar Supergroup, Hungund schists and granite gneisses of the west Dharwar craton form the basement for the Kaladgi basin sediments. The succession is divided into two groups, the Kaladgi Group and the Badami Group, separated by an angular unconformity. No definite ages for Kaladgi basin were 
available, but a tentative age from Meso-to Neo-proterozoic was being suggested from the stromatolites (Fig. 3). The lithology mainly includes conglomerate, quartz arenites, shale, micritic limestones and dolomites. The sediments overlie 2.55 Ga granites that have been intruded by pre-depositional dolerite dykes, which could provide a maximum age of deposition. Very recently $\mathrm{U}-\mathrm{Pb}$ baddeleyite age of $1861 \pm 4 \mathrm{Ma}$ is obtained for a dolerite dyke intruding the Yendigere Formation indicates the minimum age of deposition of the lower Kaladgi Group (Joy et al., 2018). This further led them to compare lower Kaladgi succession with the Papaghni Group of the Cuddapah Basin, heralding the onset of Purana sedimentation at 1900 Ma. The detrital zircon populations from the clastic rocks of the Kaladgi and Bhima basins show unique and distinct age patterns indicating the different sources of sediments for these two basins. Palaeocurrent analysis supports this notion and points to change in provenance from south or southeast to west or northwest between the Kaladgi and Bhima clastic sedimentation (Joy et al., 2018). New U-Th-Pb and $\mathrm{Rb}-\mathrm{Sr}$ radiometric dates of limestones and glauconite bearing sandstones of the Bhima Group (Bhima Basin) and the Badami Group (Kaladgi Basin) indicate deposition at around 800-900 Ma, suggesting contemporaneity for the two successions. Thus, the unconformity between the Kaladgi Group and the overlying Badami Group represents a time gap of up to 1,000 Ma.

The lowermost sequence, the Ramdurg Formation is represented by fan-delta, prodelta and shallow shelf deposits. The rifting stage of the basin evolution is attested by the immature delta succession deposited as a major fault-controlled basin and was followed by the early subsidence stage. Widespread arkose along the northern margin of the Kaladgi Basin, is interpreted predominantly as terrigenous detrital material derived from the uplifted granitic source (Dey et al., 2008). An uplifted, restricted source, dominantly consisting of Krich granitoids and pegmatites to the north of the basin supplied the immature arkosic detritus possibly under humid and warm climatic conditions (Patil Pillai and Kale, 2019; Joy et al., 2018;Dey et al., 2008). Basement uplift, folding and a hiatus in deposition follows the first cycle of sedimentation. Palaeocurrent analysis of the Ramdurg Formation of the Kaladgi basin indicates northwest to westerly flow. However, during the deposition of the Kerur Formation (Temple arenite) of the Badami Group, the flow pattern changed a little with strong bimodality towards northeast and southwest indicating tidal activity, which played a major role in sorting and sculpturing the Temple arenite. The Rabanpalli Formation of the Badami Group shows flow towards northeast and southeast. Overall changes in the palaeocurrent direction through time indicate a major shift of the provenance from southeast to northwest.

\section{Tectonic models for intracratonic basins}

Despite many studies over the years, the intracratonic basins remain poorly understood geodynamically till date (Klein, 1995; Sloss, 1992; Leighton et al., 1991; Sloss and Speed, 1974; Quinlan, 1987). They are sites of prolonged, broadly distributed but slow subsidence of the continental lithosphere, and are commonly filled with shallow water and terrestrial sedimentary rocks, with some exception of deepwater sediments. Stratigraphic and sedimentological analysis with a regional perspective, and correlation across the basin with a sequence stratigraphic approach reveals the tectonic behavior of the basins, and consequently of the craton, in time and space. The possible linkage between changes in provenance and development of basin-wide unconformities were also investigated in detail to explain these basinforming processes and to work out the relationship between tectonics and sedimentation. The basin-filling successions are characterized by the remarkable commonality of stratigraphic evolution and most of the basins, formed by a similar 'sequence of processes' (sensu Klein, 1995). These processes, in order of occurrence are: 1) lithospheric stretching, 2) mechanical, fault-controlled subsidence, and/or 3) thermal subsidence and contraction, 4) tectonic quiescent and peneplanation of the source and 5) reactivation of the faults with initiation of second cycle of sedimentation (Saha et al., 2016; Collins et al., 2015; Saha and Mazumder, 2012; Chakraborty et al., 2010; Chaudhuri et al., 2002; Patranabis-Deb and Chaudhuri, 2007a; Das et al., 1992). However, nonconformity of data received from different lines of investigation viz. geophysical, field-based, geochemical (åNd, major element etc.) etc. prompted workers to propose different models, often not in tandem.

Regionally correlatable unconformity bound sequences of the basins of Bastar, Dharwar and Bundelkhand cratons (Fig.3), similar ages for interregional unconformities that separate intracratonic sedimentary sequences, and similar trends in the thickness of the unconformity bound sequences, however, suggest a common global explanation for the origin of these basins. Near synchroneity of the ages of formation of the intracratonic basins in India, mostly with three distinct clusters, further implies the involvement of large-scale processes. It has also been observed that there are intimate relationships of the craton interior basin formation and supercontinent assembly or break up. The theory explains that during periods of fragmentation of the supercontinents, the earth's heat from interior is dissipated through mid-ocean ridges (Fischer, 1984; Worsley et al., 1984). On the other hand, during times when supercontinents formed heat loss diminished considerably and they act as heat lenses (Worsley et al., 1986; Fischer, 1984; Worsley et al., 1984;Anderson, 1982). As the supercontinents develop, particularly in the lower crust and upper mantle the rate of partial melting of continental lithosphere increases in response to focused heat flow and subsequent changes within so called stable craton interior take place.

\section{Discussion}

Between $2 \mathrm{Ga}$ and $0.54 \mathrm{Ga}$, the Earth experienced two major episodes of supercontinent accretion, followed by supercontinent breakup (Rogers and Santosh, 2002; 2004; Worsley et al., 1986; Bond et al., 1984; Condie, 1982). Despite the fact that older supercontinent's reconstruction is not easy due to destruction of older crust, suggestions of Precambrian supercontinents are coming up and they are often being questioned (Stern et al., 2016; Brown, 2008; Stern, 2008, 2007; Dewey, 2007; Davies, 1992) or being accepted by many (Meert and Santosh, 2017; Nance et al., 2014; Meert, 2012; Cawood and Pisarevsky, 2006). The Palaeoproterozoic supercontinent Columbia (between 2.5 and $1.5 \mathrm{Ga}$ with maximum packing around 1.9 to 1.7 Ga) (Nance et al., 2014; Meert, 2012; Santosh and Kusky, 2010; Hou et al., 2008; Rogers and Santosh, 2002; Zhao et al., 2002; 2004) and Neoproterozoic Rodinia (between $~ 1.1-0.9$ Ga with maximum packing around $1.1 \mathrm{Ga}$ ), (Burrett and Berry, 2002; Sears and Price, 2002; Piper, 2000; Dalziel, 2000;Karlstrom et al., 1999; Brookfield, 1993) is now well accepted. Significantly enough, our limited published geochronologic data indicate that the evolutionary history of the cratonic basins ofpeninsular India overlaps with the timing of assembly and dispersal of these two supercontinents. 
It has been observed that the tectonic processes at the craton margins controlled the basin initiation and evolution processes of the Purana basins. The basins are distributed either near trans-Indian middle Proterozoic mobile belts or fold belts (Fig. 2). The characteristics and similarities among the orogenic belts of India suggest that the crustal architecture of India, developed during the Proterozoic period possibly through the stitching of several microcontinents, though uncertainties remain due to an inadequate palaeomagnetic database (summarized in Li et al., 2008).

\section{Timing of opening and closure of the Purana basins}

Basal mafic intrusions within the Cuddapah basin yielded 1.9 Ga date (Ar-Ar and U-Pb age from baddeleyite and zircon), which points to basin opening stage (Vadlamani et al., 2014; French et al., 2008; Anand et al., 2003). Basal Kaladgi is reported to be older than $1861 \pm 4 \mathrm{Ma}$ (U-Pb baddeleyite age) as obtained for a dolerite dyke intruding the lower Kaladgi Group (Joy et al., 2018). From the Bijawar basin, Bundelkhand craton, the Dargawan sill has yielded dates of $1789 \pm 21 \mathrm{Ma}, 1691 \pm 180 \mathrm{Ma}$ and $1967 \pm 140$ Ma by Rb-Sr systematics (Pandey et al., 2012; Haldar and Ghosh, 2000). Initiation of sedimentation of the Vindhyan Basin is obtained from the Porcellanite Formation to be 1631 Ma age (Rasmussen et al., 2002; Ray et al., 2002), while $\mathrm{Pb}-\mathrm{Pb}$ ages of the Kajrahat Limestone below the Porcelanite Formation indicate that the sedimentation took place earlier than 1721Ma (Ray, 2006; Sarangi et al., 2004). The new data by Collins et al., (2015) suggest that the Nallamalai Group correlates temporally and tectonically with the Somanpalli Group of the Pranhita-Godavari Valley Basin, which is tightly constrained to be deposited at $\sim 1620$ Ma. Based on geochronology of supposed granulite facies rocks in the Bhopalpatnam area on the eastern flank of the PGV, Santosh et al. (2004) suggested a $\sim 1.6$ Ga collisional event leading to the Godavari Join between the Bastar and the Dharwar cratons. They also postulate a rifting event at $1.5 \mathrm{Ga}$, which led to the developmentof the Proterozoic sequences of the PGV. Glauconites from Mallampalli sandstones yielded a plateau age of $1686 \pm 6$ Ma, whereas those from the Mulug and Somanpalli Groups yielded ages of $1565 \pm 6 \mathrm{Ma}$ and $1620 \pm 6 \mathrm{Ma}$, respectively (Amarasinghe et al., 2015; Conrad et al., 2011). Zircon (U-Pb SHRIMP) and Monazite (U-Th-Total Pb CHIME) dating from a tuffaceous unit present at the basal part of Singhora Group of Chhattisgarh Supergroup allowed workers to believe initiation of Chhattisgarh sedimentation around 1450 Ma ago (Das et al., 2009; Bickford et al., 2011). Comparable ages were also obtained from Khariar (1455 \pm 47 Ma, Das et al., 2009) and Ampani (1446 \pm 21 Ma, Das et al., 2015) basins to suggest that either a master basin or a string of coeval basins of varied dimensions opened around $\sim 1450$ Ma in the eastern margin of the Indian craton (Fig. 3 \& 4).

However, closure of these basins are marked by the presence of rhyolitic tuff at the top of the Indravati and Chhattisgarh successions, which have been dated between ca. 990 Ma and 1020 Ma (Bickford et al., 2014, 2011; Mukherjee et al., 2012;Patranabis-Deb et al., 2007). $\mathrm{Pb}-\mathrm{Pb}$ age of limestone units from the uppermost part of the Vindhyan succession is $\sim 1000 \mathrm{Ma}$ (Gopalan et al., 2013). Paleomagnetic pole positions and provenance analysis from detrital zircon geochronology

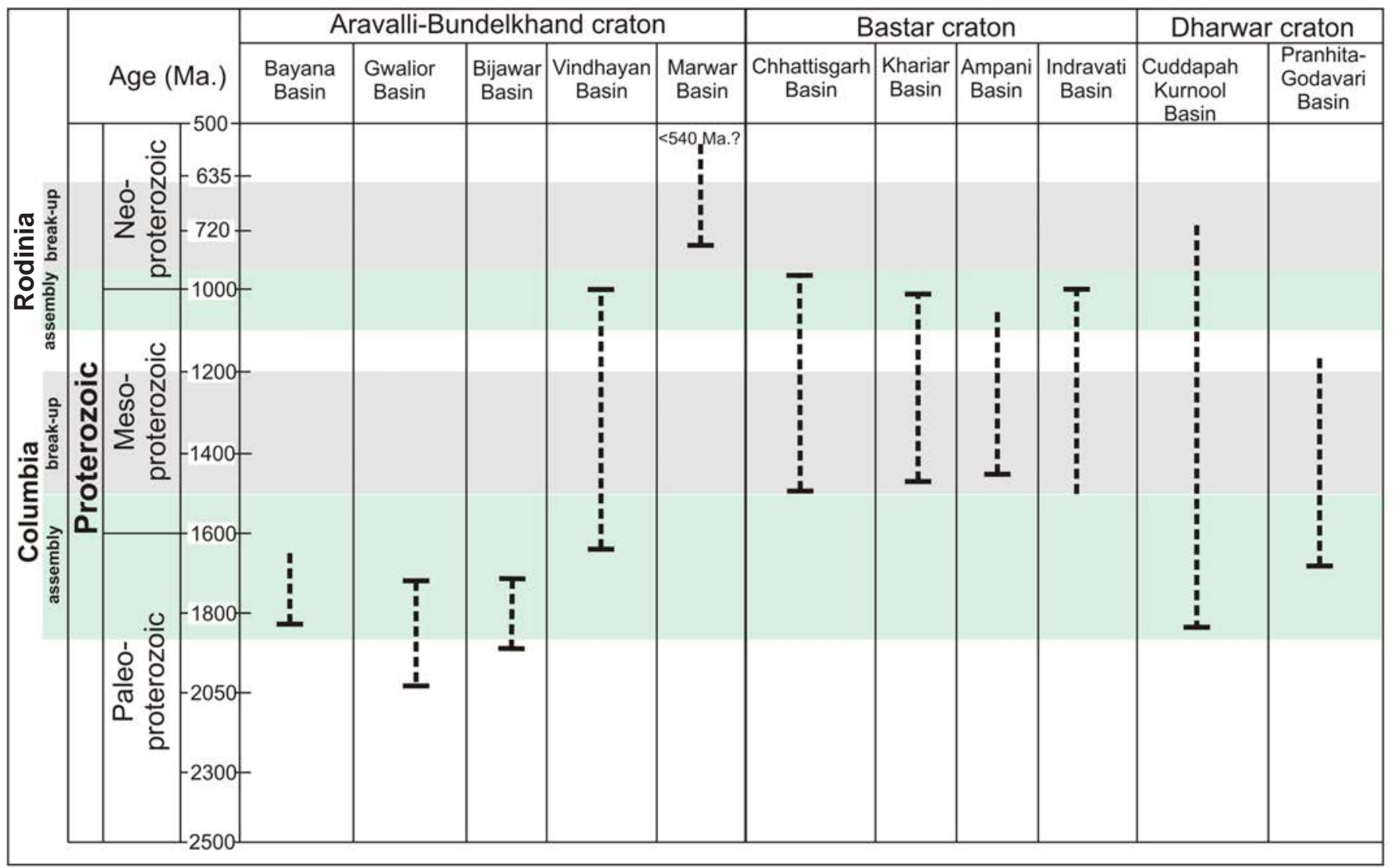

Figure 4. Shows the time of initiation and closure of the Proterozoic sedimentary basins in context of amalgamation and fragmentation of Columbia and Rodinia Supercontinent. 
yielded similar age for the upper Vindhyans (e.g., Turner et al., 2014; Davis et al., 2014;Malone et al., 2008). The age of the Bhima succession is further constrained by two glauconite sandstone samples analysed yielding ages of $\sim 800 \mathrm{Ma}$ and $\mathrm{Pb}-\mathrm{Pb}$ work on a series of limestone samples yielding an approximate age of $\sim 910$ Ma (Joy et al., 2018). The closure of the Marwar basin is constrained to ca. 540 Ma by U-Pb ages of detrital zircons in the upper part of the succession (McKenzie et al., 2011). It is likely that most of the Purana basins (Vindhyan, Chhattisgarh, Indravati, Khariar, Ampani, Abujhmar, Sukma-Sabari, Albaka, Mallampalli, Palnad, Srisailam, Kurnool, and Bhima) closed between 900 Ma and 1000 Ma. This closure age coincides with orogenesis in the Eastern Ghats (Korhonen et al., 2011) and the Central Indian Tectonic Zone (Bhowmik et al., 2019, 2012).

Further, recent geochronological appraisal and paleomagnetic pole reconstruction data from the major cratonic blocks of East India, Western Australia and East Antarctica have argued for their contemporaneity in the Columbia architecture (Mohanty, 2011). The detritus record can also be potentially used to check the correlativity among the continental blocks, particularly those from the cratonmargin sedimentary basins juxtaposed to Mesoproterozoic orogenic belts. For example, the age population from the Chhattisgarh, Khariar and Ampani basin, irrespective of their stratigraphic variation can be clubbed as a whole into three age groups, viz. Archean (3700-3500 Ma), Palaeoproterozoic (2780-2320 Ma) and Mesoproterozoic (1700$1500 \mathrm{Ma}$ ). Tracking the similarities, if any, the available detrital zircon dataset from other carton-margin sedimentary basins developed adjacent to or within the crustal-scale orogenic belts in the pre'Rodinia' transcontinental scenario. For example, bordering the western margin of the Yilgarn craton, the Albany-Fraser Orogen hosts two large sparsely outcropped metasedimentary packages and correlated with the Central Indian Tectonic Zone (Harris, 1993). Detrital zircon geochronology of these Paleo- to Mesoproterozoic metasedimentary successions (Barren basin, 1.8-1.6 Ga, Arid basin, 1.6-1.3 Ga, Spaggiari et al., 2014, 2011) from the Albany-Fraser Orogen have a reported maximum depositional age younger than $\sim 1625$ Ma. Besides, 3300-1550 Ma and very little concentration of $>3300$ Ma ages are also reported from the Barren basin. From the Arid basin reported ages are $\sim 2750-2450 \mathrm{Ma}, \sim 2200-2000 \mathrm{Ma}$ and $\sim 1850-1325$ Ma (Spaggiari et al., 2015). Whereas sediment source for the Barren basin is identified as the Yilgarn craton, provenance for the Arid basin is proposed as the Loongana arc ( 1410 Ma) of the Madura Province. It is also reported that the Arid basin changed from a passive margin to a convergent margin setting at $\sim 1455 \mathrm{Ma}$ coinciding with the flipping of easterly dipping subduction towards west and change of basin deposition in a foreland moat. Interestingly, the $\sim 1450 \mathrm{Ma}$ arc magmatism is also reported in the recent time from the East Indian craton (Das et al., 2015). Further, consideration of detrital zircon dates available from metasedimentary packages of East Antarctica also reveal similar age distribution patterns, i.e. Tingey Complex 3500-2250 Ma, Lambert Group 3500-1700 Ma and Sodruzhestvo Group 3500-1700 Ma (Phillips et al., 2006). All these together indicate that similar craton-margin shallow crustal processes can be traced beyond East Indian Bastar craton to its erstwhile neighbors of Antarctica and Australia. Further data from other continents as well as other parts of the Indian continent will strengthen the correlation in the future.

The message transmitted by the above review indicates further studies required to get a complete idea of opening of the Purana basins. Our data indicate that the basins of Dharwar craton initiated during final phases of amalgamation of the first coherent supercontinent Columbia where nearly all of earth's continental blocks were tightly packed between 1.9 to $1.5 \mathrm{Ga}$. Around 1.9-1.8 Ga, the eastern India, Australia, and Antarctica were sutured to western North America (Rogers and Santosh, 2004, 2002) and finally to the main landmass stated above. Zao et al. (2004) put forward a different model with a slight deviation from the original model proposed by Rogers and Santosh (2002). They attached North China to India with a zigsaw fit of Trans-North China Orogen to central Indian Tectonic Zone and concluded that the assembly of the supercontinent Columbia was completed by global-scale collisional events during 2.1-1.8 Ga. The opening of the Purana basins of Dharwar craton thus can be correlated to the breakup of the supercontinent of Columbia where the supercontinent broke into smaller plates with an increase in heat flow underneath. Crust immediately above partially melted zones might have been thinned, thus favoring localized and regional stretching. Ideally, this configuration would have accounted for stretching within the crust above areas of anorogenic granite intrusion and partial melting during supercontinent breakup. The proposed basin-forming mechanism for the origin of intracratonic basins poses two consequences. First, below older Precambrian intracratonic basins, where the root zones are exposed, anorogenic granite should occur. Second, the formation of intracratonic basins follows major collisional orogenic events. Finally, it must be emphasized that this model of basin formation of intracratonic basins requires further testing.

\section{Concluding Remarks}

The Indian craton remains a major element in the debate on the make-up and configuration of both the supercontinent Columbia and Rodinia with widely varying views in reconstructions (Pisarevsky et al., 2003; Kröner and Cordani, 2003; Torsvik, 2003;Dalziel, $1997 ;$ Hoffman, 1991). The problem is intensified because of the overlap between the last stage of amalgamation of the supercontinents in geological records of one continent and the first stage of break up in another continent. Thus, it is clear that the time of amalgamation and breakup of any supercontinent varies between continents. The esolution of the problem requires intensive studies of Proterozoic basin-filling successions, backed up by precise age data and paleomagnetic data.

\section{Acknowledgements}

We thank Prof. P. P. Chakraborty for inviting us to write this review. Infrastructure at Indian Statistical Institute and Wadia Institute of Himalayan Geology helped us to complete the manuscript. Anonymous reviewers are thanked for their constructive reviews.

\section{References}

Absar, N., 2005. Geology and geochemistry of Paleoproterozoic Gwalior Group sediments, Bundelkhand craton, Central India: implications for provenance, depositional environment, tectonic setting and evolutionary trend of upper continental crust, Ph.D thesis.

Absar, N., Raza, M., Roy, M., Naqvi, S.M., and Roy, A.K., 2009, Composition and weathering conditions of Paleoproterozoic upper crust of Bundelkhand craton, Central India: records from geochemistry of clastic sediments of 1.9 Ga Gwalior Group. 
Precambrian Research, v. 168, pp. 313-329.

Acharyya, S.K., 2003, A plate tectonic model for Proterozoic crustal evolution of Central Indian tectonic zone. Gondwana Geological Magazine, v. 7, pp. 9-31.

Akhtar, K., 1996, Facies, sedimentation processes and environments in the Proterozoic Vindhyan Basin, India. Geological Society of India Memoir, pp. 127-136.

Allen, P.A, and Allen J.R., 2005, Basin Analysis: Principles and Applications, 2nd Edition. ISBN: 978-0-632-05207-3. WileyBlackwell. pp. 560.

Allen, P.A., and Armitage, J.J., 2012, Cratonic basins. Tectonics of sedimentary basins: Recent advances, pp.602-620.

Amarasinghe, U., Chaudhuri, A., Collins, A.S., Deb, G. and Patranabis-Deb, S., 2015, Evolving provenance in the Proterozoic Pranhita-Godavari Basin, India. Geoscience Frontiers, v. 6, pp. 453-463.

Anand, M., Gibson, S.A., Subbarao, K.V., Kelley, S.P., and Dickin, A.P., 2003, Early Proterozoic melt generation processes beneath the intra-cratonic Cuddapah basin, Southern India. Journal of Petrology, v. 44, pp. 2139-2171.

Anderson, D.L., 1982, Hotspots, polar wander, Mesozoic convection and the geoid. Nature, v. 297, pp. 391-393.

Ansari, A.H., Pandey, S.K., Sharma, M., Agrawal, S., and Kumar, Y., 2018, Carbon and oxygen isotope stratigraphy of the Ediacaran Bilara Group, Marwar Supergroup, India: Evidence for high amplitude carbon isotopic negative excursions. Precambrian Research, v. 308, pp. 75-91.

Artemieva, I.M., 2007, Dynamic topography of the East European craton: Shedding light upon lithospheric structure, composition and mantle dynamics. Global and Planetary Change, v. 58, pp. 411-434.

Banerjee, I., 1974, Barrier coast line sedimentation model and the Vindhyan example. Quarterly Journal Geological Mining Meteorological Society of India (Golden Jubilee Volume), v. 46, pp. 101-127.

Banerjee, S., Jeevankumar, S. and Eriksson, P.G., 2008. Mg-rich ferric illite in marine transgressive and highstand systems tracts: examples from the Paleoproterozoic Semri Group, central India. Precambrian Research 162: 212-226.

Banerjee, S. and Jeevankumar, S., 2005. Microbially originated wrinkle structures on sandstone and their stratigraphic context: Palaeoproterozoic Koldaha Shale, central India. Sedimentary Geology 176: 211-224.

Banerjee, S. and Jeevankumar, S., 2007. Facies and depositional sequence of the Mesoproterozoic Rohtas Limestone: eastern Son valley, India. Journal of Asian Earth Sciences 30: 82-92.

Banerjee, S., Bhattacharya, S.K. and Sarkar, S., 2007. Carbon and oxygen isotopic variations in peritidal stromatolite cycles, Paleoproterozoic Kajrahat Limestone, Vindhyan basin of central India. Journal of Asian Earth Sciences 29: 823-831.

Banerjee, S., Sarkar, S., Eriksson, P.G., 2014. Palaeoenvironmental and biostratigraphic implications of microbial mat-related structures: examples from modern Gulf of Cambay and Precambrian Vindhyan basin. Journal of Paleogeography 3, 127144.

Basumallick, S., 1967, Problems of the Purana stratigraphy of the Godavari valley with special reference to the type area in Warangal district, Andhra Pradesh, India. Quarterly Journal of the Geological, Mining, Metallurgical Society of India, v. 39, pp. 115-127.

Basu, A., and Bickford, M.E., 2015, An alternate perspective on the opening and closing of the intracratonic Purana Basins in Peninsular India. Journal of Geolocial Society of India, v. 85, pp. 5-25.
Bengtson, S., Belivanova, V., Rasmussen, B., and Whitehouse, M., 2009, The controversial "Cambrian" fossils of the Vindhyan are real but more than a billion years older. Proceedings of National Academy of Sciences, v. 106, pp. 7729-7734.

Bhaskar Rao, Y.J., Pantulu, G.V.C., Damodara Reddy, V. and Gopalan, N.V., 1995, Time of early sedimentation and volcanism in the Proterozoic Cuddapah Basin, South India: evidence from the RbSr age of Pulivendla mafic sill. In: T.C. Devaraju (Ed.), Mafic Dyke Swarms of Peninsular India. Geolological Society of India Memoir, v.33, pp. 329-338.

Bhowmik, S.K., Wilde, S.A., Bhandari, A., Pal, T., and Pant, N.C., 2012, Growth of the Greater Indian Landmass and its Assembly in Rodinia: Geochronological evidence from the Central Indian Tectonic Zone. Gondwana Research, v. 22, pp. 54-72.

Bhowmik, S.K., 2019, The current status of orogenesis in the Central Indian TectonicZone: A view from its Southern Margin. Geological Journal, pp. 1-23.

Bickford, M.E., Basu, A., Patranabis-Deb, S., Dhang, P.C., and Schieber, J., 2011, Depositional history of the Chhattisgarh basin, Central India: Constraints from new SHRIMP zircon ages. The Journal of Geology, v. 119, pp. 33-50.

Bickford, M.E., Basu, A., Kamenov, G.D., Mueller, P.A., PatranabisDeb, S. and Mukherjee, A., 2014, Petrogenesis of 1000 Ma felsic tuffs, Chhattisgarh and Indravati basins, Bastar craton, India: Geochemical and Hf isotope constraints. The Journal of Geology, v. 122, pp. 43-54.

Biswal, T.K., Sinha, S., Mandal, A., Ahuja, H., and Das, M.K., 2003, Deformation pattern of Bastar craton adjoining Eastern Ghat mobile belt, NW Orissa. Gondwana Geological Magazine, Special Publication, v. 7, pp. 101-108.

Biswas, S.K., 2003, Regional tectonic framework of the PranhitaGodavari Basin: Journal of Asian Earth Sciences, v. 21, pp. 543551.

Bond, G.C., Nickeson, P.A. and Kominz, M.A., 1984, Breakup of a supercontinent between $625 \mathrm{Ma}$ and $555 \mathrm{Ma}$ : new evidence and implications for continental histories. Earth and Planetary Science Letters, v. 70, pp. 325-345.

Bose, P.K., Banerjee, S., and Sarkar, S., 1997. Slope-controlled seismic deformation and tectonic framework of deposition, Koldaha Shale, India. Tectonophysics, v. 269, pp. 151-169.

Bose, P.K., Chakraborty, S., and Sarkar, S., 1999, Recognition of ancient aeolianlongitudinal dunes: a case study from the Upper Bhander sandstone, Sonvalley, India. Journal of Sedimentary Research, v. 69, pp. 86-95.

Bose, P.K., Sarkar, S., Chakraborty, S., and Banerjee, S., 2001, Overview of the Meso-to-Neoproterozoic evolution of the Vindhyan basin, central India. Sedimentary Geology, v. 141, pp. 395-419.

Brown, M., 2008, Geodynamic regimes and tectonic settings for metamorphism: relationship to the supercontinent cycle. Indian Journal of Geology, v. 80, pp. 3-21.

Brookfield, M.E., 1993, Neoproterozoic Laurentia-Australia fit. Geology, v. 21, pp. 683-686.

Burrett, C. and Berry, R., 2002, A statistical approach to defining Proterozoic crustal provinces and testing continental reconstructions of Australia and Laurentia-SWEAT or AUSWUS?. Gondwana Research, v. 5, pp. 109-122.

Cawood, P.A., and Pisarevsky, S.A., 2006, Was Baltica right-way-up or upside-down in the Neoproterozoic? Journal of Geological Society, v. 163, pp. 753-759.

Chadwick, B., Vasudev, V.N., and Hegde, G.V., 2000, The Dharwar craton, southern India, interpreted as the result of Late Archaean oblique convergence. Precambrian Research, v. 99, pp. 91-111.

Chakrabarti R., Basu A.R., and Chakrabarti A., 2007, Trace element 
and Nd-isotopic evidence for sediment sources in the midProterozoic Vindhyan Basin, central India. Precambrian Research, v. 159 , pp. $260-274$.

Chakraborty, C., and Bhattacharyya, A., 1996, Fan-delta sedimentation in a foreland moat: Deoland Formation, Vindhyan Supergroup, Son valley. Geological Society of India Memoir, pp. 27-48.

Chakraborty, P.P., Sarkar, S., and Bose, P.K., 1998, A viewpoint on intracratonic chenier evolution: clue from a reappraisal of the Proterozoic Ganurgarh Shale, central India. The Indian Precambrians (ed.) Palliwal BS (Jodhpur: Scientific Publishers, India), pp. 61-72.

Chakraborty, T. and Chakraborty, C., 2001, Eolian-aqueous interactions in the development of a proterozoic sand sheet: Shikaoda Formation, Hosangabad, India. Journal of Sedimentary Research, v. 71, pp. 107-117.

Chakraborty, P.P., Sarkar, A., Bhattacharya, S.K., Sanyal, P., 2002, Isotopic and sedimentological clues to productivity change in late Riphean sea: a case study from two intracratonic basins of India. Proceedings Indian Academy of Science, v. 111, pp. 379-390.

Chakraborty, P.P., 2004, Facies architecture and sequence development in a Neoproterozoic carbonate ramp: Lakheri Limestone member, Vindhyan Supergroup, central India. Precambrian Research, v. 132, pp. 29-53.

Chakraborty C., 2006, Proterozoic intracontinental basin: theVindhyan example. Journal of Earth System Science, v. 115, pp. 3-22.

Chakraborty, P.P., 2006, Outcrop signatures of relative sea levelfall on a siliciclastic shelf: Examples from the Rewa Group ofProterozoic Vindhyan Basin. Journal of Earth System Science, v. 115, pp. 23-36.

Chakraborty, P.P., Paul, S., 2008. Forced regressive wedges on a Neoproterozoic siliciclastic shelf: Chandarpur Group, central India. Precambrian Research 162, 227-247.

Chakraborty, P.P., Sarkar, A., Das, K., and Das, P., 2009, Alluvial fan to storm-dominated shelf transition in the Mesoproterozoic Singhora Group, Chhattisgarh Supergroup, central India. Precambrian Research, v. 170, pp. 88-106.

Chakraborty, P.P., Dey, S., and Mohanty, S.P., 2010, Proterozoic platform sequences of Peninsular India: Implications towards basin evolution and supercontinent assembly. Journal of Asian Earth Sciences, v. 39, pp. 589-607.

Chakraborty, P.P. and Paul, P., 2014, Depositional character of a dryclimate alluvial fan system from Palaeoproterozoic rift setting using facies architecture and palaeohydraulics: Example from the Par Formation, Gwalior Group, central India. Journal of Asian Earth Sciences, v. 91, pp. 298-315.

Chakraborty, P.P., Pant, N.C., and Paul, P.P., 2015a, Controls on sedimentation in Indian Palaeoproterozoic basins: clues from the Gwalior and Bijawar basins, central India. Geological Society, London, Memoirs, v. 43, pp. 67-83.

Chakraborty, P. P., Saha, S., and Das, P., 2015b, Geology of Mesoproterozoic Chhattisgarh Basin, central India: current status and future goals. Geological Society of London, Memoirs, v. 43, pp. 185-205.

Chakraborty, P.P., Saha, S., and Das, K., 2017, Record of continental to marine transition from the Mesoproterozoic Ampani basin, Central India: An exercise of process-based sedimentology in a structurally deformed basin. Journal of Asian Earth Sciences, v. 143, pp.122-140.

Chaudhuri, A.K., 1985, Stratigraphy of the Purana Supergroup around Ramagundam, Andhra Pradesh. Journal of Geological Society of India, v. 26, pp. 301-314.

Chaudhuri, A.K., Mukhopadhyay, J., Deb, S.P. and Chanda, S.K., 1999. The Neoproterozoic cratonic successions of peninsular
India. Gondwana Research, v. 2, pp. 213-225.

Chaudhuri, A.K., 2003, Stratigraphy and palaeogeography of the Godavari Supergroup in the south-central Pranhita-Godavari Valley, south India. Journal of Asian Earth Sciences, v. 21, pp. 595-611.

Chaudhuri, A.K. and Deb, G.K., 2004, Proterozoic rifting in the Pranhita-Godavari Valley: implication on India-Antarctica linkage. Gondwana Research, v. 7, pp. 301-312.

Chaudhuri, A.K., Deb, G.K., Patranabis-Deb, S., and Sarkar, S., 2012. Paleogeographic and tectonic evolution of the Pranhita-Godavari Valley, Central India: a Stratigraphic perspective. American Journal of Science, v. 312, pp. 766-815.

Chaudhuri, A.K., Deb, G.K., and Patranabis-Deb, S., 2015, Conflicts in stratigraphic classification of the Puranas of the PranhitaGodavari Valley: review, recommendations and status of the 'Penganga'sequence. Geological Society, London, Memoirs, v. 43, pp. 165-183.

Chalapathi Rao, N.V., Miller, J.A., Pyle, D.M., and Madhavan, V., 1996, New Proterozoic K- Ar ages for some kimberlites and lamproites from the Cuddapah basin and Dharwar craton, southern India. Precambrian Research, v. 79, pp. 363-369.

Chalapathi Rao, N.V., Miller, J.A., Gibson, S.A., Pyle, D.M., and Madhavan, V., 1999, Precise 40Ar/39Ar age determinations of the Kotakonda kimberlite and Chelima lamproite, India: implication for the mafic dyke swarm emplacement in the Eastern Dharwar craton. Journal of Geological Society of India, v. 53, pp. $425-432$.

Chalapathi Rao, N.V., Kamde, G., Kale, H.G., and Dongre, A., 2010, Mesoproterozoic lamproites from the Krishna Valley, Eastern Dharwar craton, southern India: Petrogenesis and diamond prospectivity. Precambrian Research, v. 177, pp. 103-130.

Chalapathi Rao, N.V., Atiullah, A.K., Sahoo, S., Nanda, P., Ngazimpi, N.C., Lehmann, B., and Rao, K.V.S., 2016, Petrogenesis of Mesoproterozoic lamproite dykes from the Garledinne (Banganapalle) cluster, south-western Cuddapah Basin, southern India. Mineralogy \& Petrology, v. 110, pp. 247-268.

Chanda, S.K., and Bhattacharya, A., 1982, Vindhyan sedimentation and paleogeography: post-Auden developments. In: Valdiya, K.S., Bhatia, S.B., Gaur, V.K. (Eds.), Geology of Vindhyachal. Hindustan Publishers, Corporation, New Delhi, pp. 88-101.

Chapman, D.S., and Pollack, H.N., 1974, “Cold spot” in West Africa: anchoring the African plate. Nature, v. 250, pp. 477-478.

Chatterjee, N., and Bhattacharji, S., 2001, Petrology, geochemistry and tectonic settings of the mafic dikes and sills associated with the evolution of the Proterozoic Cuddapah Basin of south India. Proc. Indian Academy of Science (Earth Planet. Sci), v. 110, pp. 433-453.

Chaudhuri, A.K., Saha, D., Deb, G.K., Patranabis-Deb, S., Mukherjee, M.K., and Ghosh, G., 2002, The Purana basins of Southern Cratonic province of India: A case for Mesoproterozoic fossil rifts. Gondwana Research, v. 5, pp. 23-33.

Chauhan, D.S., Ram, B., and Ram, N., 2004, Jodhpur Sandstone: A gift of ancient beaches to western Rajasthan. Journal of Geological Society of India, v. 64, pp. 265-276.s

Chilingar, G.V., Harold, J., Bissell, H.J., and Wolf, K.H., 1967, Chapter 5 Diagenesis of Carbonate Rocks. Developments in Sedimentology, v. 8, pp. 179-322.

Cocks, L.R.M., and Torsvik, T.H., 2002, Earth geography from 500 to 400 million years ago: a faunal and paleomagnetic review. Journal of Geological Society London, v. 159, pp. 631-644.

Collins, A.S., Patranabis-Deb, S., Alexander, E., N. Bertram, C.N., Falster, G.M., Gore, R.J., Mackintosh, J., Dhang, P.C., Saha, D., Payne, J.L., Jourdan, F., Backé, G., Halverson, G.P, and Wade, B.P., 2015, Detrital Mineral Age, Radiogenic Isotopic Stratigraphy 
and Tectonic Significance of the Cuddapah Basin, India. Gondwana Research, v. 28, pp. 1294-1309

Condie, K.C., 1982, Plate-tectonics model for Proterozoic continental accretion in the southwestern United States. Geology, v. 10, pp. 37-42.

Conrad, J.E., Hein, J.R., Chaudhuri, A.K., Patranabis-Deb, S., Mukhopadhyay, J., Deb, G.K., and Beukes, N.J., 2011, Constraints on the development of Proterozoic basins in central India from 40Ar/39Ar analysis of authigenic glauconitic minerals. Bulletin, v. 123, pp. 158-167.

Crawford, A.R., and Compston, W., 1970, The age of the Vindhyan system of peninsular India: Journal of Geological Society of London, v. 125, pp. 351-371.

Crawford, A.R., and Compston, W., 1973, The age of the Cuddapah and Kurnool systems, Southern India. Journal of the Geological Society of Australia, v. 19, pp. 453-464.

Dalziel, I.W., 1997, OVERVIEW: Neoproterozoic-Paleozoic geography and tectonics: Review, hypothesis, environmental speculation. Geological Society of America Bulletin, v. 109, pp. 16-42.

Dalziel, I.W., Lawver, L.A. and Murphy, J.B., 2000, Plumes, orogenesis, and supercontinental fragmentation. Earth and Planetary Science Letters, v. 178, pp. 1-11.

Das, D.P., Kundu, A., Das, N., Dutta, D.R., Kumaran, K., Ramamurthy, S., Thangavelu, C., and Rajaiya, V., 1992, Lithostratigraphy and sedimentation of Chhattisgarh basin. Indian Minerals, v. 46, pp. 271-288.

Das, D.P., Dutta, N.K., Dutta, D.R., Thanavelu, C., and Baburao, K., 2003, Singhora Group the oldest Proterozoic lithopackage of Eastern Bastar Craton and its significance. Indian Mineral, v. 57, pp. 127-138.

Das, K., Yokoyama, K., Chakraborty, P.P., and Sarkar, A., 2009, Basal tuffs and contemporaneity of the Chhattisgarh and Khariar basins based on new dates and geochemistry. Journal of Geology, v. 117, pp. 88-102.

Das, N., Dutta, D.R., and Das, D.P., 2001, Proterozoic cover sediments of southeastern Chhattisgarh state and adjoining parts of Orissa. Geological Survey of India, Special Publication, v. 55, pp. 237262.s

Das, P., Das, K., Chakraborty, P.P., and Balakrishnan, S., 2011, 1420 Ma diabasic intrusives from the Mesoproterozoic Singhora Group, Chhattisgarh Supergroup, India: Implications towards non-plume intrusive activity. Journal of Earth System Science, v. 120, pp. 223-236.

Das, K., Chakraborty, P.P., Hayasaka, Y., Kayama, M., Saha, S., and Kimura, K., 2015, c.1450 Ma regional felsic volcanism at the fringe of the East Indian Craton: constraints from geochronology and geochemistry of tuff beds from detached sedimentary basins. Geological Society, London, Memoirs, v. 43, pp. 207-221.

Das, K., Chakraborty, P.P., Horie, K., Tsutsumi, Y., Saha, S., and Balakrishnan, S., 2017, Detrital zircon U-Pb geochronology, Nd isotope mapping, and sediment geochemistry from the Singhora Group, Central India: implications toward provenance, its shift, and regional stratigraphic correlation. In Sediment Provenance, Elsevier, pp. 403-451

Datta, B., 1998, Stratigraphic and sedimentologic evolution of the Proterozoic siliciclastics in the southern part of Chhattisgarh and Khariar, Central India. Journal of Geological Society of India, v. 51, pp. 345-360.

Davies, G.F., 1992, On the emergence of plate tectonics. Geology, v. 20, pp. 963-966.

Davis, J.K., Meert, J.G., and Pandit, M.K., 2014, Paleomagnetic analysis of the Marwar Supergroup, Rajasthan, India and proposed interbasinal correlations. Journal of Asian Earth Sciences, v. 91, pp. 339-351.
De, C., 2006, Ediacara fossil assemblage in the Upper Vindhyans of Central India and its significance. Journal of Asian Earth Sciences, v. 27, pp. 660-683.

Deb, M., Thorpe, R., and Krstic, D., 2002, Hindoli Group of Rocks in the Eastern Fringe of the Aravalli-Delhi Orogenic Belt-Archean Secondary Greenstone Belt or Proterozoic Supracrustals? Gondwana Research, v. 5, pp. 879-883.

Dewey, J.F., 2007, The secular evolution of plate tectonics and the continental crust: An outline. Memoirs-Geological Society of America, v. 200, pp. 1.

Dey, S., Rai, A.K., and Chaki, A., 2008, Widespread Arkose along the Northern margin ofthe Proterozoic Kaladgi Basin, Karnataka: product of uplifted Granitic source or K-metasomatism? Journal Geological Society of India, v. 71, pp. 79-88.

Fischer, A.G., 1984, The two Phanerozoic supercycles, in Berggren, W.A., and van Couvering, J.A., eds., Catastrophes and Earth history: Princeton, New Jersey, Princeton University Press, pp. 129-150

French, J.E., Heaman, L.M., Chacko, T., and Rivard, B., 2008, 18911883 Ma southern Bastar craton-Cuddapah mafic igneous events, India: a newly recognized large igneous province. Precambrian Research, v. 160, pp. 308-322.

Ghosh, G., and Saha, D., 2003, Deformation of the proterozoic Somanpalli group, Pranhita-Godavari Valley, South Indiadimplication for a Mesoproterozoic basin inversion. Journal of Asian Earth Science, v. 21, pp. 579-594.

Ghosh, G., and Saha, D., 2005, Kinematics of large scale asymmetric folds and associated smaller scale brittle-ductile structures in the Proterozoic Somnur Formation, Pranhita-Godavari valley, South India. Journal of Earth System Science, v. 114, 125-142.

Gopalan, K., Kumar, A., Kumar, S., and Vijaygopal, B., 2013, Depositional history of the Upper Vindhyan succession, central India: Time constraints from $\mathrm{Pb}-\mathrm{Pb}$ isochron ages of its carbonate components. Precambrian Research, v. 233, pp. 108-117.

Gregory, L.C., Meert, J.G., Pradhan, V., Pandit, M.K., Tamrat, E., and Malone, S.J., 2006. A paleomagnetic and geochronologic study of the Majhgawan kimberlite, India: implications for the age of the Upper Vindhyan Supergroup. Precambrian Research, v. 149, pp. 65-75.

Gregory, L.C., Meert, J.G., Bingen, B., Pandit, M.K., and Torsvik, T.H., 2009, Paleomagnetism and geochronology of the Malani Igneous Suite, Northwest India: implications for the configuration of Rodinia and the assembly of Gondwana. Precambrian Research, v. 170 , pp. $13-26$.

Gurnis, M., 1988. Large-scale mantle convection and the aggregation and dispersal of supercontinents. Nature, v. 332, pp. 695-699.

Haldar, D., and Ghosh, R.N., 2000, Eruption of Bijawar lava: an example of Precambrian volcanicity under stable cratonic conditions. Geological Survey of India, Hyderabad, Special Publications, v. 57, pp. 151-170.

Halverson, G.P., Hurtgen, M.T., Porter, S.M., and Collins, A.S., 2009, Neoproterozoic-Cambrian biogeochemical evolution. In: Gaucher C, Sial AN, Halverson GP, Frimmel HE (eds) NeoproterozoicCambrian Tectonics, Global Change and Evolution: A Focus on Southwestern Gondwana. Developments in Precambrian Geology 16, Elsevier, pp. 351-365.

Harris, L.B., 1993, Correlations between the Central Indian Tectonic Zone and the Albany Mobile Belt of Western Australia: evidence for a continuous Proterozoic orogenic belt. In Gondwana 8: assembly, evolution and dispersal, CRC Press/Balkema, pp. 165180.

Hartley R.W., and Allen, P.A., 1994, Interior cratonic basins of Africa: relation to continental break-up and role of mantle convection. Basin Research, v. 6, pp. 95-113. 
Heron, A. M., 1932, The Vindhyans of western Rajputana Records. Geological Survey of India, v. 65, pp. 457-489.

Hoffman, P.F., 1991, Did the breakout of Laurentia turn Gondwanaland inside out? Science, v. 252, pp. 1409-1412.

Holland, T.H., 1907, The Imperial Gazetteer of India: The Indian Empire Volume 1 (Descriptive). Oxford, pp. 50-103.

Ingersoll, R.V., 2012, Composition of modern sand and Cretaceous sandstone derived from the Sierra Nevada, California, USA, with implications for Cenozoic and Mesozoic uplift and dissection. Sedimentary Geology, v. 280, pp. 195-207.

Jayananda, M., Banerjee, M., Pant, N.C., Dasgupta, S., Kano, T., Mahesha, N., and Mahabaleswar, B., 2012. 2.62 Ga hightemperature metamorphism in the central part of the Eastern Dharwar Craton: Implications for late Archaean tectonothermal history. Geological Journal, v. 47, pp. 213-236.

Jayananda, M., Chardon, D., Peucat, J.J., and Fanning, C.M., 2015, Paleo- to Mesoarchean TTG accretion and continental growth, western Dharwar craton, southern India: SHRIMP U-Pb zircon geochronology, whole-rock geochemistry and Nd-Sr isotopes. Precambrian Research, v. 268, pp. 295-322.

Jayananda, M., Duraiswami, R.A., Aadhiseshan, K.R., Gireesh, R.V., Prabhakar, B.C., Kafo, Kowe-u., Tushipokla, and Namratha, R., 2016, Physical volcanology and geochemistry of Palaeoarchaean komatiite lava flows from the western Dharwar craton, Southern India: implications for Archaean mantle evolution and crustal growth. International Geology Review, v. 58, pp. 1569-1595.

Jayananda, M., Santosh, M., and Aadhiseshan, K.R., 2018, Formation of Archean (3600-2500 Ma) continental crust in the Dharwar Craton, southern India. Earth-Science Reviews, v. 181, pp. 1242.

Jayaprakash, A.V., Sundaram, V., Hans, K., and Mishra, R.N., 1987, Geology of Kaladgi-Badami Basin, Karnataka. In: Purana Basins of Peninsular India. Geological Society of India Memoir, v. 6, pp. 201-225.

Jessop, A.M., and Lewis, J.J., 1978, Heat flow and heat generation in the superior province of the Canadian shield. Tectonophysics, v. 50, pp. 55-77.

Jayaprakash, A.V., 2007, Purana basins of Karnataka. Geological Survey of India Memoir, v. 129, pp. 136.

Joy, S., Jelsma, H.A., Preston, R.F., and Kota, S., 2012, Geology and diamond provenance of the Proterozoic Banganapalle conglomerates, Kurnool Group, India. Geological Society, London, Special Publications, v. 365, pp.197-218.

Joy, S., Patranabis Deb, S., Saha, D., Jelsma, H., Maas, R., Söderlund, U., Tappe, S., van der Linde, G., Banerjee, A., and Krishnan, U., 2018, Depositional history and provenance of cratonic "Purana” basins in southern India: A multipronged geochronology approach to the Proterozoic Kaladgi and Bhima basins. Geological Journal, pp. 1-23. doi.org/10.1002/gj.3415.

Kaila, K.L., Roy-Choudhury, K., Reddy, P.R., Krishna, V.G., Narain, H., Subbotin, S.I., Sollugub, V.B., Chekunov, A.V., Kharetchiko, G.E., Lazarenko, M.A., and Ilchenko, T.V., 1979, Crustal structure along Kavali-Udipi profile in the Indian Peninsular shield from deep seismic soundings. Journal of Geological Society of India, v. 20, pp. 307-333.

Karlstrom, K.E., Harlan, S.S., Williams, M.L., McLelland, J., Geissman, J.W. and Ahall, K.I., 1999, Refining Rodinia: Geologic evidence for the Australia-western US connection in the Proterozoic. GSA Today, v. 9, pp. 1-7.

Klein, G.D., 1995, Intracratonic Basins, in Busby, C.J., and Ingersoll, R.V., eds., Tectonics of sedimentary basins. Oxford, Blackwell Science, pp. 459-478.

Korhonen, F.J., Saw, A.K., Clark, C., Brown, M., and Bhattacharya, S., 2011, New constraints on UHT metamorphism in the Eastern
Ghats Province through the application of phase equilibria modelling and in situ geochronology. Gondwana Research, v. 20, pp. 764-781.

Kröner, A., and Cordani, U.G., 2003, African, southern Indian and South American cratons were not part of the Rodinia supercontinent: evidence from field relationships and geochronology. Tectonophysics, v. 375, pp. 325-352.

Kumar, A., Gopalan, K., Rao, K.R.P., and Nayak, S.S., 2001, Rb-Sr ages of kimberlites and lamproites from Eastern Dharwar Craton, south India: Journal of Geological Society of India, v. 58, pp. 135-141.

Kumar, S., and Pandey, S.K., 2008a, Arumberia and associated fossils from the Neoproterozoic Maihar Sandstone, Vindhyan Supergroup, Central India. Journal of the Palaeontological Society of India, v. 53, pp. 83-97.

Kumar, S., and Pandey, S. K., 2008b, Discovery of trilobite trace fossils from the Nagaur Sandstone, the Marwar Supergroup, Bikaner District, Rajasthan. Current Science, v. 94, pp. 10811085.

Kumar, S., and Pandey, S.K., 2010, Trace fossils from the Nagaur Sandstone, Marwar Supergroup, Dulmera area, Bikaner district, Rajasthan, India. Journal of Asian Earth Sciences, v. 38, pp. 7785.

Kutas, R.I., 1977, Investigation of heat flow in the territory of the Ukraine. Tectonophysics, v. 41, pp. 139-145.

Lehmann, B., Mainkar, D. and Belyatsky, B., 2006, The Tokapal craterfacies kimberlite system, Chhattisgarh, India: Reconnaissance petrography and geochemistry. Journal of Geological Society of India, v. 68, pp. 9.

Lehmann, B., Storey, C., Mainkar, D., and Jeffries, T., 2007, In-situ $\mathrm{U}-\mathrm{Pb}$ dating of titanite in the Tokapal-Bhejripadar kimberlite system, central India. Journal of Geological Society of India, v. 69, pp. 553-556.

Leighton, M.W., Kolata, D.R., Oltz, D.F., and Eidel, J.J., 1991 (eds) Interior cratonrc basins: American Association of Petroleum Geologists Memoir, v. 5l, pp. 819.

Li, Z.X., Bogdanova, S.V., Collins, A.S., Davidson, A., De Waele, B., Ernst, R.E., Fitzsimons, I.C.W., Fuck, R.A., Gladkochub, D.P., Jacobs, J., Karlstrom, K.E., Lu, S., Natapov, L.M., Pease, V., Pisarevsky, S.A., Thrane, K., and Vernikovsky, V., 2008, Assembly, configuration, and break-up history of Rodinia: a synthesis. Precambrian Research, v. 160, pp. 179-210.

Manikyamba, C., Ganguly, S., Santosh, M., and Subramanyam, K.S.V., 2017, Volcano-sedimentary and metallogenic records of the Dharwar greenstone terranes, India: Window to Archean plate tectonics, continent growth, and mineral endowment. Gondwana Research, v. 50, pp. 38-66.

Maithy, P.K., and Kumar, G., 2007, Biota in the terminal Proterozoic successions on the Indian subcontinent: a review. Geological Society, London, Special Publications, v. 286, pp. 315-330.

Malone, S., Meert, J., Banerjee, D.M., Pandit, M., Tamrat, E., Kamenov, G.D., Pradhan, V., and Sohl, L.E., 2008, Paleomagnetism and detrital zircon geochronology of theUpper Vindhyan Sequence, Son Valley and Rajasthan, India:A ca. 1000 Ma closure age for the Purana Basins? Precambrian Research, v. 164, pp. 137-159.

Mondal, M.E.A., Goswami, J.N., Deomurari, M.P. and Sharma, K.K., 2002, Ion microprobe $207 \mathrm{~Pb} / 206 \mathrm{~Pb}$ ages of zircons from the Bundelkhand massif, northern India: implications for crustal evolution of the Bundelkhand-Aravalli protocontinent. Precambrian Research, v. 117, pp. 85-100.

Mondal, M.E.A., 2009, Was Bundelkhand-Aravalli nucleus part of Ur supercontinent? Current Science, v. 96, pp. 33-35.

Mainkar, D., Lehmann, B., and Haggerty, S.E., 2004, The crater- 
facies kimberlite system of Tokapal, Bastar district, Chhatisgarh, India. Lithos, v. 76, pp. 201-217.

McKenzie, N.R., Hughes, N.C., Myrow, P.M., and Sharma, M., 2011. Correlation of Precambrian-Cambrian sedimentary successions across northern India and the utility of isotopic signatures of Himalayan lithotectonic zones. Earth and Planetary Science Letters, v. 312, pp. 471-483.

Meert, J.G., and Lieberman, B.S., 2004, A palaeomagnetic and palaeobiogeographical perspective on latest Neoproterozoic and early Cambrian tectonic events. Journal of the Geological Society, v. 161, pp. 477-487

Meert, J.G., Pandit, M.K., Pradhan, R., Banks, J., Sirianni, R., Stroud, M., Newstead, B., and Gifford, J., 2010, Precambrian crustal evolution of Peninsular India: a 3.0 billion year odyssey. Journal Asian Earth Sciences, v. 39, pp. 483-515.

Meert, J.G., 2012, What's in a name? The Columbia (Paleopangaea/ Nuna) supercontinent. Gondwana Research, v. 21, pp. 987-993.

Meert, J.G., Pandit, M.K., Pradhan, V.R., Banks, J., Stroud, M., Newstead, B., and Gifford, J., 2010, Precambrian crustal evolution of Peninsular India: a 3.0-billion-year odyssey. Journal of Asian Earth Sciences, v. 39, pp. 483-515

Meert, J.G., 2012, What's in a name? The Columbia (Paleopangaea/ Nuna) supercontinent. Gondwana Research, v. 21, pp. 987-993.

Meert, J.G., and Santosh, M., 2017, The Columbia supercontinent revisited. Gondwana Research, v. 50, pp. 67-83.

Miall, A.D., 2005, Testing for eustatic sea-level control in the Precambrian sedimentary record. Sedimentary Geology, v. 176, pp. 9-16.

Misra, R.N., Jayaprakash, A.V., Hans, S.K., and Sundaram, V., 1987, Bhima Group of Upper Proterozoic - A Stratigraphic puzzle: Geological Society of India Memoir, v. 6, pp. 227-237.

Mishra, D.C., Sekhar, D.C., Raju, D.C.V., and Kumar, V.V., 1999, Crustal structure based on gravity-magnetic modelling constrained from seismic studies under Lambert Rift, Antarctica and Godavari and Mahanadi rifts, India and their interrelationship. Earth and Planetary Science Letters, v. 172, pp. 287-300.

Mohanty, S., 2011, Palaeoproterozoic assembly of the Napier Complex, Southern India and Western Australia: implications for the evolution of the Cuddapah basin. Gondwana Research, v. 20, pp. 344-361.

Mondal, M.E.A., 2009, Was Bundelkhand-Aravalli nucleus part of Ur supercontinent? Current Science, v. 96, pp. 33-35.

Mukherjee, A., Bickford, M.E., Hietpas, J., Schieber, J., and Basu, A., 2012, Implications of a newly dated ca. 1000-Ma rhyolitic tuff in the Indravati Basin, Bastar Craton, India. The Journal of Geology, v. 120, pp. 477-485.

Murti, K.S., 1987, Stratigraphy and sedimentation in Chhattisgarh basin. In:Radhakrishna, B.P. (Ed.), Purana Basins of Peninsular India, vol. 6. Geological Societyof India, (Memoir), pp. 239-260.

Nagaraja Rao, B.K., Rajurkar, S.T., Ramalingaswamy, G., and Ravindra-Babu, B., 1987, Stratigraphy, structure and evolution of the Cuddapah basin. Purana basins of Peninsular India. Geological Society of India Memoir, v. 6, pp. 33-86.

Nance, R., Murphy, J., and Santosh, M., 2014, The supercontinent cycle: A retrospective essay. Gondwana Research, v. 25, pp. 429.

Naqvi, S.M., and Rogers, J.J.W., 1987, Precambrian Geology of India: New York, Oxford University Press, pp. 223.

Pandey, O.P., and Agrawal, P.K., 1999, Lithospheric mantle deformation beneath the Indian cratons. Journal of Geology, v. 107, pp. 683-692.

Pandey, U.K., Sastry, D.V.L.N., Pandey, B.K., Roy, M., Rawat, T.P.S., Ranjan, R., and Shrivastava, V.K., 2012, Geochronological (Rb$\mathrm{Sr}$ and $\mathrm{Sm}-\mathrm{Nd}$ ) studies on intrusive gabbros and dolerite dykes from parts of Northern and Central Indian cratons: Implications for the age of onset of sedimentation in Bijawar and Chattisgarh basins and uranium mineralisation. Journal of the Geological Society of India, v. 79, pp. 30-40.

Pandey, S.K., and Kumar, S., 2013, Organic walled microbiota from the silicified algal clasts, Bhander limestone, Satna area, Madhya Pradesh. Journal of Geological Society of India, v. 82, pp. 499508.

Paul, S., 2006, Facies, palaeogeography and depositional sequence analyses in parts of Meso- to Neoproterozoic rocks of Chattishgarh Supergroup, India. Unpub. Ph.D. Thesis, Indian School of Mines, Dhanbad, 153 p.

Patil Pillai, S., and Kale, V.S., 2019, Interplay Between Tectonics \& Eustacy in a Proterozoic Epicratonic, Polyhistory Basin, North Dharwar Craton In: Tectonics and Structural Geology: Indian Context (Ed Mukherjee, S) Springer Geology, pp. 75-114.

Patranabis-Deb, S., and Chaudhuri, A.K., 2007a, A retreating fandelta system in the Neoproterozoic Chattisgarh rift basin, central India: major controls on its evolution. AAPG Bulletin, v. 91, pp. 785-808.

Patranabis-Deb, S., Bickford, M.E., Hill, B., Chaudhuri, A.K., and Basu, A., 2007b, SHRIMP ages of zircon in the uppermost tuff in Chattisgarh Basin in central India require up to $\sim 500 \mathrm{Ma}$ adjustment in Indian Proterozoic stratigraphy. Journal of Geology, v. 15, pp. 407-415.

Patranabis-Deb, S., and Chaudhuri, A.K., 2008, Sequence Evolution in the Eastern Chattisgarh Basin: Constraints on Correlation and Sequence Analysis. Palaeobotanist, v. 57, pp. 15-32.

Patranabis-Deb, S., Chaudhuri, A.K., 2010, Sedimentological products and processes in the Mesoproterozoic Chattisgarh basin and contemporary tectonics in Central India. Indian Journal of Geology, v. 80, pp. 139-155.

Patranabis-Deb, S., Saha, D., and Tripathy, V., 2012, Basin stratigraphy, sea-level fluctuations andtheir global tectonic connections e evidence from the Proterozoic Cuddapah Basin. Geological Journal, v. 47, pp. 263-283.

Patranabis-Deb, S., S³0wakiewicz, M., Tucker, M.E., Pancost, R.D., and Bhattacharya, P., 2016, Carbonates and related facies with vestiges of biomarkers from the Chattisgarh Basin, India: Clues to redox conditions in the Mesoproterozoic ocean. Gondwana Research, v. 35, pp. 411-424.

Pisarevsky, S.A., Biswal, T.K., Wang, X.C., De Waele, B., Ernst R., Soderland, U., Tait, J.A., Ratre, K., Singh, Y.K., Cleve, M., 2013, Palaeomagnetic, geochronological and geochemical study of Mesoproterozoic Lakhna Dykes in the Bastar Craton, India: implications for the Mesoproterozoic supercontinent. Lithos, v. 174, pp. 125-143.

Pareek, H.S., 1984, Pre-Quaternary geology and mineral resources of northwestern Rajasthan. Geological Survey of India, v. 115.

Patil Pillai, S., and Kale, V.S., 2019, Interplay between tectonics and eustasy in a Proterozoic epicratonic polyhistory basin: Kaladgi basin, north Dharwar craton. In S. Mukherjee (Ed.), Tectonics and structural geology: Indian context. Springer, Cham: Springer Geology, pp. 75- 114. doi.org/10.1007/978 331999341 6_4

Paul, P.P., 2017, Autogenic and continental and marine sedimentation Allogenic controls on late Paleoproterozoic sedimentation: clues from Gwalior rift basin, Central India. Unpublished Ph.D. thesis, University of Delhi, Delhi, India.

Phillips, G., Wilson, C.J., Campbell, I.H., and Allen, C.M., 2006, U$\mathrm{Th}-\mathrm{Pb}$ detrital zircon geochronology from the southern Prince Charles mountains, east Antarctica-defining the Archaean to Neoproterozoic Ruker province. Precambrian Research, v. 148, pp. 292-306.

Piper, J.D., 2000, The Neoproterozoic supercontinent: Rodinia or 
Palaeopangaea?. Earth and Planetary Science Letters, v. 176, pp. 131-146.

Pisarevsky, S.A., Wingate, M.T., Powell, C.M., Johnson, S., and Evans, D.A., 2003, Models of Rodinia assembly and fragmentation. Geological Society, London, Special Publications, v. 206, pp. 35-55.

Prasad, B., and Verma, K.K., 1991, Vindhyan basin: A review. Sedimentary basins of India, pp. 50-62.

Prasad, B., 2007, Obruchevella and other terminal Proterozoic (Vendia) organic-walled microfossils from the Bhander Group (Vindhyan Supergroup), Madhya Pradesh. Journal of Geolocical Society of India, v. 69, pp. 295-310.

Quinlan, G., 1987, Models of subsidence mechanisms in intracratonic basins, and their applicability to North American examples.

Rai, A.K., Pandey, U.K., Zakaulla, S., and Parihar, P.S., 2015, New 1.9-2.0 Ga, Pb-Pb (PbSL), Age of Dolomites from Vempalle Formation, Lower Cuddapah Supergroup, Eastern Dharwar Craton, India. Journal of the Geological Society of India, v. 86, pp. 131-136.

Rai, V., and Singh, V.K., 2004, Discovery of Obruchevella Reitlinger, 1948 from the late Palaeoproterozoic lower Vindhyan succession and its significance. Journal of Palaeontological Society of India, v. 49, pp. 189-196.

Ratre, K., De Waele, B., Biswal, T.K., and Sinha, S., 2010, SHRIMP geochronology for the 1450 Ma Lakhna dyke swarm: Its implication for the presence of Eoarchaean crust in the Bastar Craton and 1450-517 Ma depositional age for Purana basin (Khariar), Eastern Indian Peninsula. Jour. Asian Earth Science, v. 39, pp. 565-577.

Radhakrishna, B.P., and Naqvi, S.M., 1986, Precambrian continental crust of India and its evolution. Journal of Geolology, v. 94, pp. 145-166

Radhakrishna, B.P., and Vaidyanadhan, R., 1994, Geology of Karnataka, Geol. Soc. of India. pp. 298

Ramakrishnan, M., 1987, Stratigraphy, sedimentary environment and evolution of the Late Proterozoic Indravati basin, central India. In: Radhakrishna, B.P. (Ed.), Purana Basins of Peninsula India. Geological Society of India Memoir, v. 6, pp. 139- 160.

Ram, J., Shukla, S.N., Pramanik, A.G., Varma, B.K., Chandra, G., and Murthy, M.S.N., 1996, Recent investigations in the Vindhyan basin: implications for the basin tectonics. Geological Society of India Memoirs, pp. 267-286.

Ramakrishna, M., Vaidyanadhan, R., 2008, Geology of India, vol. I. Geological Society of India, Bangalore, pp. 556.

Ramakrishnan, M., and Vaidyanadhan, R., 2010. Geology of India (Vol. 1 \& 2). Geological survey of India, Publications, 2(1).

Ramesh, D.S., Bianchi, M.B., and Sharma, S.D., 2010, Images of possible fossil collision structures beneath the Eastern Ghats belt, India, from $\mathrm{P}$ and $\mathrm{S}$ receiver functions. Lithosphere, v. 2, pp. 8492.

Rasmussen, B., Bose, P.K., Sarkar, S., Banerjee, S., Fletcher, I.R., and McNaughton, N.J., 2002, 1.6 Ga U-Pb zircon age for the Chorhat Sandstone, lower Vindhyan, India:possible implications for early evolution of animals. Geology, v. 30, pp. 103-106.

Rao, J.M., Rao, G.P., Widdowson, M., and Kelley, S.P., 2005, Evolution of Proterozoic mafic dyke swarms of the Bundelkhand Granite Massif, central India. Current Science, v. 88, pp. 502506.

Ratre, K., De Waele, B., Biswal, T.K., and Sinha, S., 2010, SHRIMP geochronology for the 1450 Ma Lakhna dyke swarm: Its implication for the presence of Eoarchaean crust in theBastar Craton and 1450-517 Ma depositional age for Purana basin (Khariar), Eastern Indian Peninsula. Journal of Asian Earth Sciences, v. 39, pp. 565-577.
Vadlamani, R., Hashmi, S., Chatterjee, C., Ji, W.Q., and Wu, F.Y., 2014, Initiation of the intra-cratonic Cuddapah basin: evidence from Paleoproterozoic (1995 Ma) anorogenic porphyritic granite in Eastern Dharwar Craton basement. Journal of Asian Earth Sciences, v. 79, pp. 235-245.

Ray, J.S., 2006, Age of the Vindhyan Supergroup: A review of recent findings. Journal of Earth System Science, v. 115, pp. 149-160.

Ray, J.S., Martin, M.W., Veizer, J., and Bowring, S.A., 2002, U-Pb zircon dating and Sr isotope systematic of the Vindhyan Supergroup, India. Geology, v. 30, pp. 131-134.

Ray, J.S., Veizer, J., and Davis, W.J., 2003, C, O, Sr and Pb isotope systematics of carbonate sequences of the Vindhyan Supergroup, India: age, diagenesis, correlations and implications for global events. Precambrian Research, v. 121, pp. 103-140.

Raza, M., and Casshyap, S.M., 1996, A tectono-sedimentary model of evolution of middle Proterozoic Vindhyan basin. Geological Society of India Memoirs, pp. 287-300.

Roy, A.B., 1988, Stratigraphic and tectonic framework of the Aravalli Mountain Range. Precambrian of the Aravalli Mountain Rajasthan, India, pp.3-31.

Rogers, J.J.W., and Callahan, E.J., 1987, Radioactivity, heat flow and rifting of the Indian continental crust. Journal of Geology, v. 95; pp. 829-836.

Rogers, J.J.W., and Santosh, M., 2002, Configuration of Columbia, a Mesoproterozoic supercontinent. Gondwana Research, v. 5, pp. $5-22$.

Rogers, J.J.W., and Santosh, M., 2004, Continents and Supercontinents. Oxford University Press, New York, pp. 289

Saha, D., 1988, Deformational controls in and lithostratigraphy of cherla formation, Albaka Belt South India.

Saha, D., and Chakraborty, S., 2003, Deformation pattern in the Kurnool and Nallamalai groups in the northeastern part (Palnad area) of the Cuddapah basin, South India and its implication on Rodinia. Gondwana Research, v. 6, pp. 73-83.

Saha, D., Chakraborti, S., and Tripathy, V., 2010, Intracontinental thrusts and inclined transpression along eastern margin of the East Dharwar Craton, India. Journal of Geological Society of India, v. 75, pp. 323-337.

Saha, D., and Tripathy, V., 2012, Palaeoproterozoic sedimentation in the Cuddapah Basin, south India and regional tectonics: a review. Geological Society, London, Special Publications, v. 365, pp. 161184.

Saha, D., and Mazumder, R., 2012, An overview of the Paleoproterozoic geology of peninsular India, and key stratigraphic and tectonic issues. In: Mazumder R, Saha D (eds) Paleoproterozoic of India. Geological Society London Sp Publ, v. 365, pp. 5-29

Saha, S., Das, K., Chakraborty, P.P., Das, P., Karmakar, S., and Mamtani, M.A., 2013, Tectono-magmatic evolution of the Mesoproterozoic Singhora basin, central India: Evidence for compressional tectonics from structural data, AMS study and geochemistry of basic rocks. Precambrian Research, v. 227, pp. 276-294.

Saha, D., and Patranabis-Deb, S., 2014, Proterozoic evolution of Eastern Dharwar and Bastar cratons, India-an overview of the intracratonic basins, craton margins and mobile belts. Journal of Asian Earth Sciences, v. 91, pp. 230-251.

Saha, D., Patranabis-Deb, S., and Collins, A.S., 2016, Proterozoic Stratigraphy of Southern Indian Cratons and Global Context. In: Montenari, M. (ed), Stratigraphy \& Timescales, Elsevier, 1, pp. 1-59

Saha, S., Das, K., Hidaka, H., Kimura, K., Chakraborty, P.P. and Hayasaka, Y., 2016, Detrital zircon geochronology (U-Pb SHRIMP and LA-ICPMS) from the Ampani Basin, Central India: 
Implication for provenance and Mesoproterozoic tectonics at East Indian cratonic margin. Precambrian Research, v. 281, pp. 363383.

Santosh, M., Yokoyama, K., and Acharyya, S. K., 2004, Geochronology and tectonic evolution of Karimnagar and Bhopalpatnam granulite belts, Central India: Gondwana Research, v. 7, pp. 501-518,

Sarangi, S., Gopalan, K., and Kumar, S., 2004, Pb-Pb age of earliest megascopic eukaryotic alga bearing Rohtas Formation, Vindhyan Supergroup, India: Implications for Precambrian atmospheric oxygen evolution. Precambrian Research, v. 132, pp. 107-121.

Sass, J.H., and Lachenbruch, A.H., 1979, Thermal regime of the Australian continental crust. In McElhinny,M.W., ed. The Earth, its origin, structure and evolution.London, Academic Press, pp. 301-351.

Sears, J.W., and Price, R.A., 2002, The hypothetical Mesoproterozoic supercontinent Columbia: implications of the Siberian-west Laurentian connection. Gondwana Research, v. 5, pp. 35-39.

Seilacher, A., Bose, P.K., and Pflüger, F., 1998, Triploblastic animals more than 1 billion years ago: trace fossil evidence from India. Science, v. 282, pp. 80-83.

Sharma, M., 2008, Neoproterozoic biotic signatures in the peninsular Indian Basins- An Overview. Geological Society of India Memoir, v. 74, pp. 119-131.

Sharma, R.S., 2009, Aravalli Mountain Belt. In Cratons and Fold Belts of India. Springer, Berlin, Heidelberg, pp. 143-176.

Shrivastava, B.P., 1971, Rock-stratigraphic Nomenclature for the Sedimentaries of West-central Rajasthan (No. 44). Geological, Mining and Metallurgical Society of India.

Singh, I.B., 1980, The Bijaigarh shale, Vindhyan system (Precambrian), India-an example of a lagoonal deposit. Sedimentary Geology, v. 25, pp. 83-103.

Singh, I.B., 1985, Palaeogeography of Vindhyan Basin and its relationship with other late Proterozoic basins of India. Journal of Paleontological Society of India, v. 30, pp. 35-41.

Singh, S.P., 1988, Stratigraphy and sedimentation pattern in the Proterozoic Delhi Supergroup, northwestern India. MemoirsGeological Society of India, v. 7, pp. 193-206.

Sloss, L.L., 1972, Synchrony of Phanerozoic tectonic events of North America and Russian platform: Proceedings of the 24th International Geological Congress, section 4, pp. 320-328.

Sloss, 1991, Epilog, in Leighton, M.W., Kolata, D.R., Oltz, D.F., and Eidel, J.J., editors, Interior Cratonic Basins. American Association of Petroleum Geologist Memoir 51, pp. 799-805.

Sloss, L.L., 1992, Tectonic episodes of cratons: Conûicting North American concepts. Terra Nova, v. 4, pp. 320-328.

Sloss, L.L., and Speed, R.C., 1974, Relationships of cratonic and continental-margin tectonic episodes, in: Tectonics and Sedimentation, W.R. Dickinson, ed., SEPM Special Publication. pp. 98-119.

Soni, M.K., Chakraborty, S., and Jain, V.K., 1987, Vindhyan Supergroup: A Review. Journal of Geological Society of India Memoir, v. 6, pp. 87-118.

Soares, P.C., Landim, P.M.B., and Fulfaro, V.J., 1978, Tectonic cycles and sedimentary sequences in the Brazilian intracratonic basins. Geological Society of America Bulletin, v. 89, pp. 181-191.

Spaggiari, C.V., Kirkland, C.L., Pawley, M.J., Smithies, R.H., Wingate, M.T.D., Doyle, M.G., Blenkinsop, T.G., Clark, C., Oorschot, C.W., Fox, L.J., and Savage, J., 2011, The geology of the east Albany-Fraser Orogen — a field guide: Geological Survey of Western Australia, Record, v. 23, pp. 97.

Spaggiari, C.V., Kirkland, C.L., Smithies, R.H., and Wingate, M.T.D., 2014, Tectonic links between sedimentary cycles, basin formation and magmatism in the Albany-Fraser Orogen, Western Australia:
Geological Survey of Western Australia Report, Report, v. 133, pp. 63.

Spaggiari, C.V., Kirkland, C.L., Smithies, R.H., Wingate, M.T.D., and Belousova, E.A., 2015, Transformation of an Archean craton margin during Proterozoic basin formation and magmatism: The Albany-Fraser orogen, Western Australia. Precambrian Research, v. 266, pp. 440-466.

Srinivasa Rao, K., Sreenivasa Rao, T., and Rajagopalan Nair, S., 1979, Stratigraphy of the upper Precambrian Albaka belt, east of Godavari river in Andhra Pradesh and Madhya Pradesh. Journal of Geological Society of India, v. 20, pp. 205-213.

Srivastava, P., 2009, Trachyhystrichosphaera: An age-marker acanthomorph from the Bhander group, upper Vindhyan, Rajasthan. Journal of Earth System Sciences, v. 118, pp. 575582.

Stern, R.J., 2007, When and how did plate tectonics begin? Theoretical and empirical considerations. Chinese Science Bulletin, v. 52, pp.578-591.

Stern, R.J., 2008, Neoproterozoic crustal growth: the solid Earth system during a critical episode of Earth history. Gondwana research, v. 14, pp. 33-50.

Stern, R.J., Leybourne, M.I., and Tsujimori, T., 2016, Kimberlites and the start of plate tectonics. Geology, v. 44, pp. 799-802.

Subba Raju, M., Sreenivasa Rao, T., Setti, D.N., and Reddi, B.S.R., 1978, Recent advances in our knowledge of the Pakhal Supergroup with special reference to the Central part of the Godavari Valley. Records of Geological Survey of India, v. 110, pp. 39-59.

Thomson, D., Rainbird, R.H., and Dix, G., 2014. Architecture of a Neoproterozoic intracratonic carbonate ramp succession: Wynniatt Formation, Amundsen Basin, Arctic Canada. Sedimentary Geology, v. 299, pp. 119-138.

Tackley, P.J., 2000, Self-consistent generation of tectonic plates in time-dependent, three-dimensional mantle convection simulations. Geochemistry, Geophysics, Geosystems, v. 1 (8).

Torsvik, T.H., Carter, L.M., Ashwal, L.D., Bhushan, S.K., Pandit, M.K., and Jamtveit, B., 2001, Rodinia refined or obscured: palaeomagnetism of the Malani igneous suite (NW India). Precambrian Research, v. 108, pp. 319-333.

Torsvik, T.H., 2003, The Rodinia Jigsaw Puzzle. Science, v. 300, pp. 1379-1381.

Turner, C.C., Meert, J.G., Pandit, M.K., and Kamenov, G.D., 2014, A detrital zircon $\mathrm{U} ? \mathrm{~Pb}$ and $\mathrm{Hf}$ isotopic transect across the Son Valley sector of the Vindhyan Basin, India: Implications for basin evolution and paleogeography. Gondwana Research, v. 26, pp. 348-364.

Vadlamani, R., Hashmi, S., Chatterjee, C., Ji, W.Q., and Wu, F.Y., 2014, Initiation of the intra-cratonic Cuddapah basin: evidence from Paleoproterozoic (1995 Ma) anorogenic porphyritic granite in Eastern Dharwar Craton basement. Journal of Asian Earth Sciences, v. 79, pp. 235-245.

Valentine, J.W., and Moores, E.M., 1972, Global tectonics and the fossil record. The Journal of Geology, v. 80, pp. 167-184.

Verma, R.K., and Subrahmanyam, C., 1984, Gravity anomalies ansd the Indian lithosphere: review and analysis of existing gravity data. Tectonophysics, v. 105, pp. 141-161.

Verma, R.K., and Satyanarayana, A., 1991, Gravity field, deep seismic sounding andcrust-mantle structure over the Cuddapah Basin and Dharwar craton of India.Tectonophysics, v. 178, pp. 337-356.

Verma, R.K., and Banerjee, P., 1992, Nature of continental crust along the Narmada-Son Lineament inferred from gravity and deep seismic sounding data. Tectonophysics, v. 202, pp. 375-397.

Worsley, T.R., Nance, D., and Moody, J.B., 1984, Global tectonics and eustasy for the past 2 billion years. Marine Geology, v. 58, pp. 373-400. 
Worsley, T.R., Nance, R.D., and Moody, J.B., 1986, Tectonic cycles and the history of the Earth's biogeochemical and paleoceanographic record. Paleoceanography and Paleoclimatology, v. 1, pp. 233-263.

Wignall, P.B., 1994, Black Shales. Claredon Press, Oxford, pp. 127.

Zachariah, J.K., Rao, Y.B., Srinivasan, R., and Gopalan, K., 1999, $\mathrm{Pb}, \mathrm{Sr}$ and $\mathrm{Nd}$ isotope systematics of uranium mineralised stromatolitic dolomites from the Proterozoic Cuddapah

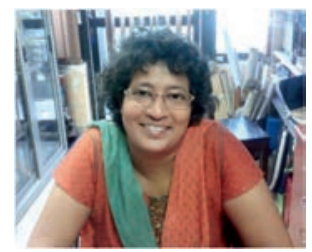

Sarbani Patranabis-Deb, Associate Professor in the Geological Studies Unit, Indian Statistical Institute, Kolkata has been working on the Proterozoic cratonic basins of peninsular India since her $P h D$ dissertation in 2001. The studies include detail geological mapping, reconstruction of stratigraphic sequence, facies classification and analysis leading to recognition of palaeoenvironment and depositional systems in these basins. The focus remains on tectono-sedimentary analysis of the successions, their interbasinal and intrabasinal correlation, ie. stratigraphic basin analysis.
Supergroup, south India: constraints on age and provenance. Chemical Geology, v. 162, pp. 49-64.

Zhao, G., Cawood, P.A., Wilde, S.A., and Sun, M., 2002, Review of global 2.1-1.8 Ga orogens: implications for a pre-Rodinia supercontinent. Earth-Science Reviews, v. 59, pp. 125-162.

Zhao, G., Sun, M., Wilde, S.A., and Li, S., 2004, A PaleoMesoproterozoic supercontinent: assembly, growth and breakup. Earth-Science Reviews. v. 67, pp. 91-123.

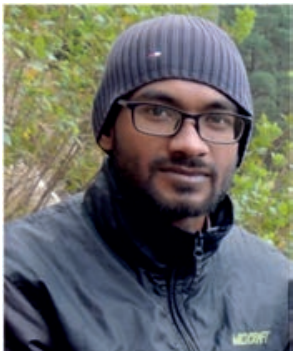

Subhojit Saha, INSPIRE Faculty in Sedimentology Group, Wadia Institute of Himalayan Geology, Dehradun. He works on sedimentology, sequence stratigraphy and detrital geochronology. At present his scientific intererest is focused on Proterozoic carbonates with a objective to identify the signatures of life and its evolution. 